\title{
Early Miocene coral reef-associated bryozoans from Colombia. Part II: "Ascophora" Cheilostomatida
}

\author{
Paola Flórez, ${ }^{1,2,3 *}$ ๑ Emanuela Di Martino, ${ }^{4}$ ๑ and Laís V. Ramalho ${ }^{5}$ \\ ${ }^{1}$ Departamento de Estratigrafía y Paleontología, Universidad de Granada, Campus Fuentenueva s/n 18002 Granada, España <paolaflorez@ \\ correo.ugr.es> \\ ${ }^{2}$ MoAm S.A. Calle 87 No. 2-45 Of. 101 Bocasalinas, Pozos Colorados, Km 8 Santa Marta-Ciénaga, Colombia <pflorez@moam.com.co> \\ ${ }^{3}$ Corporación Geológica ARES, Calle 44A No. 53-96 Bogotá, Colombia \\ ${ }^{4}$ Natural History Museum, University of Oslo, Blindern, P.O. Box 1172, Oslo 0318, Norway <e.d.martino@nhm.uio.no> \\ ${ }^{5}$ Museu Nacional, Quinta da Boa Vista, S/N São Cristóvão, Rio de Janeiro, RJ. 20940-040 Brazil <laisvr10@yahoo.com>
}

\begin{abstract}
Bryozoans are common and diverse in fossil and modern coral reefs. However, studies of bryozoans in ancient reefs are generally limited, and even less is known about fossil bryozoan faunas associated with coral reefs in the Caribbean region. This is the second contribution describing the bryozoan assemblage from the early Miocene (Aquitanian) reefs of the Siamaná Formation in the La Guajira Peninsula, southern Caribbean. Here, we describe and illustrate 17 species of ascophoran-grade cheilostomes, including one new genus and three new species, Ditaxiporina colombiana $\mathrm{n}$. sp., Poricella paulae n. sp., and Cycloavicularia parva n. gen. n. sp. Of the remaining fourteen taxa left in open nomenclature, one is considered confer and three affinis to species previously described, one is identified at family level, and nine at genus level. The Siamaná bryozoan fauna differs in species and colony-form composition from those associated with other paleoenvironments from Oligocene and Miocene localities of North America, the Caribbean, and Brazil.
\end{abstract}

UUID: http://zoobank.org/043eadcf-0e39-4c1b-b207-f7628d6b5c84

\section{Introduction}

Shallow-water coral reefs are one of the most diverse ecosystems on Earth. Their structural framework provides a suitable habitat for diverse assemblages of organisms (Graham and Nash, 2013). Bryozoans are a common and diverse component of the benthic cryptic faunas associated with these ecosystems (Winston and Jackson, 1984; Winston, 1986; Cuffey, 2011; Di Martino and Taylor, 2014, 2015; Bastos et al., 2018; Ramalho et al., 2018). However, their roles in these ecosystems remain poorly known, and the species richness of the group is underestimated in most Recent and ancient reefs (Pearman et al., 2018). Although extensive work was previously undertaken on fossil bryozoan collections from the Caribbean region (Cheetham et al., 1999; Cheetham and Jackson, 2000; Di Martino et al., 2018), early Miocene deposits, especially Aquitanian, are poorly represented. In addition, studies focused on bryozoans associated with coral reefs of this age are non-existent.

This is the second part of a comprehensive taxonomic study of the bryozoan fauna from the early Miocene deposits of the Siamaná Formation in Colombia, interpreted as shallow-water coral reefs (Flórez et al., 2019a, b). In the first contribution, we described 15 species included in the order Cyclostomatida, as well as anascan-grade and Cribrilinidae Cheilostomatida.

*Corresponding author
Here, we describe 17 species of ascophoran-grade Cheilostomatida, and discuss the results of both contributions.

\section{Geologic setting}

The Siamaná Formation is part of the sedimentary infill of the Cocinetas Basin, at the foothills of the Cocinas, Jarara, and Macuira mountain ranges, in the La Guajira Peninsula, a remote area of northern Colombia (Fig. 1.1). The formation has varying thickness ranging from $430 \mathrm{~m}$ in the type locality (Renz, 1960) to $\sim 20 \mathrm{~m}$ in the hills of Arroyo Ekieps (Fig. 1.2). It consists of basal conglomerates overlain by sandstones and fossiliferous limestones interbedded with silty clays (Rollins, 1965; Teatin, 1991). Limestones in the upper part of the Siamaná Formation include coral reefs (Rollins, 1965), some of which grew bordering the SE of the Jarara paleoisland (current highlands, Fig. 1). The studied bryozoan samples were collected in the framestone of these reefs, which developed in shallow waters with low siliciclastic input and therefore low turbidity (Flórez, 2020). The Siamaná Formation unconformably overlaps the Eocene Macarao Formation and Jurassic metamorphic rocks (Rollins, 1965). Deep marine sediments of the lower Miocene Uitpa Formation unconformably overlie the Siamaná Formation at the basin margins; however, the transition between both formations can be conformable and gradational in the central part (Rollins, 1965).

The age of the Siamaná Formation continues to be a subject of debate. Some works point to a late Oligocene age (Rollins, 

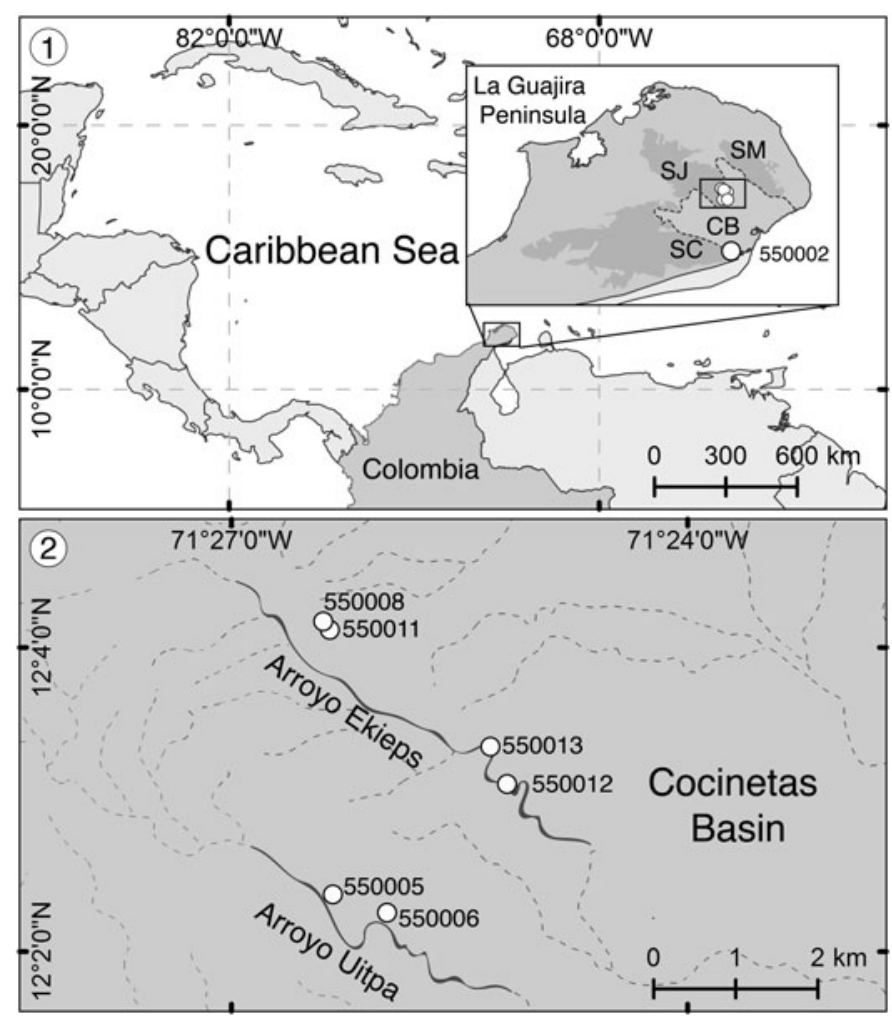

Figure 1. Locality maps from Flórez et al. (2021). (1) Location of the La Guajira Peninsula in the Caribbean region and detail of the sampled zone showing the Serranía de Cocinas (SC), Serranía de Jarara (SJ), and Serranía de Macuira (SM) surrounding the Cocinetas Basin (CB) (dotted area in the box), including the locality La Flor de La Guajira (station 550002). (2) Close-up of localities Arroyo Ekieps (stations 550008, 550011, 550012, 550013) and Arroyo Uitpa (stations 550005,550006 ) at the foothills of the Serranía de Jarara in the Cocinetas Basin.

1965; Cardenas et al., 2020; Jaramillo et al., 2020), while others suggest a diachronic deposition that reached the early Miocene (Duque-Caro, 1974; Teatin, 1991; Silva-Tamayo et al., 2017). Here, we follow Flórez (2020) and Flórez et al. (2021) who suggested an early Miocene age based on larger benthic foraminifera, and the dating provided by Silva-Tamayo et al. (2017) based on strontium isotopes of coralline algae from the same localities studied here. A revision of the lateral facies change, within the early Miocene, is needed in some parts of the Cocinetas Basin to understand the stratigraphic relationships between the Siamaná and Uitpa formations and clarify the age of the last onlapping phases of the former; however, this is beyond the scope of the present work. Additional information on the geologic and stratigraphic settings of the sampling localities is provided in Flórez et al. (2019a, fig. 2).

\section{Materials and methods}

Three localities and seven stations were sampled (Fig. 1; Appendix 1). Samples were collected by hand-picking along $10 \mathrm{~m}$ transects. The bryozoan specimens were found encrusting coral colonies, on rubble covered by coralline algae, and scattered in the sediment adhering to these hard substrates. The coral substrates were washed and the residual sediment was sieved at 250 and $63 \mu \mathrm{m}$. The better-preserved bryozoan colonies were cleaned with ultrasound, and later analyzed with scanning electron microscopy (SEM), employing FEI Quanta 400 and FEI Quemscan 650F microscopes operating at lowand high-vacuum modes, respectively. The morphometric measurements (including average, observed range, standard deviation and the number of measurements) were performed with the image-processing program Image $\mathrm{J}$ (https://imagej.nih.gov/ij), and reported in tables. The systematic paleontology follows the interim classification compiled by Gordon (2014) and the work of Winston et al. (2014). The catalog numbers and metadata of the specimens studied are supplied in Appendix 2. More details about the methods are provided in Flórez et al. (2021).

Repositories and institutional abbreviations.-All type specimens, as well as any additional material described and illustrated here, are stored in the reference collection of the Mapuka Museum of the Universidad del Norte, Barranquilla-Colombia (MUN-STRI). The type specimens of species used for comparison are housed in the following institutions: Museu Nacional, Universidade Federal do Rio de Janeiro, Brazil (MNRJ); Natural History Museum, London, UK (NHMUK); U.S. National Museum of Natural History, Washington, USA (USNM); and the Museum of Comparative Zoology, Cambridge, USA (MCZ).

\section{Systematic paleontology}

\author{
Superfamily Catenicelloidea Busk, 1852 \\ Family Catenicellidae Busk, 1852 \\ Genus Catenicella de Blainville, 1830
}

Type species.-Eucratea contei Audouin, 1826, from the Mediterranean Sea, Egypt and Syria, Recent; by original designation.

Catenicella sp. indet.

Figure 2.1-2.5; Table 1

Occurrence.-Early Miocene, Arroyo Ekieps, Siamaná Formation, La Guajira, Colombia.

Description.-Colony erect, jointed, branched, and flexible. Zooids elongate (mean L/W 3.21), pyriform, uniserially arranged, all facing the same side. Gymnocyst smooth and finely perforated. Orifice subterminal, semicircular, with a slightly raised proximal lip, forming a shallow sinus and seemingly flanked by two condyles. Infrascapular chamber with a circular to elliptical pore oriented frontally. Avicularia small with triangular rostrum, placed at the sides of the orifice, oriented frontally to laterofrontally. Suprascapular chamber ?drop-shaped, oriented distally. Vittae long and narrow, placed on both sides of the zooid, bearing 12-13 circular communication pores, beginning next to the joint and ending at the base of the lateral chamber. Abfrontal surface convex and smooth. Rhizooids and ovicells not observed. Giant avicularia unknown in our specimens.

Other material compared.-Catenicella uberrima (Harmer, 1957) Recent, Arraial do Cabo (Forno Beach), Rio de Janeiro State, Brazil, $1.5 \mathrm{~m}$ depth, MNRJ-136. 

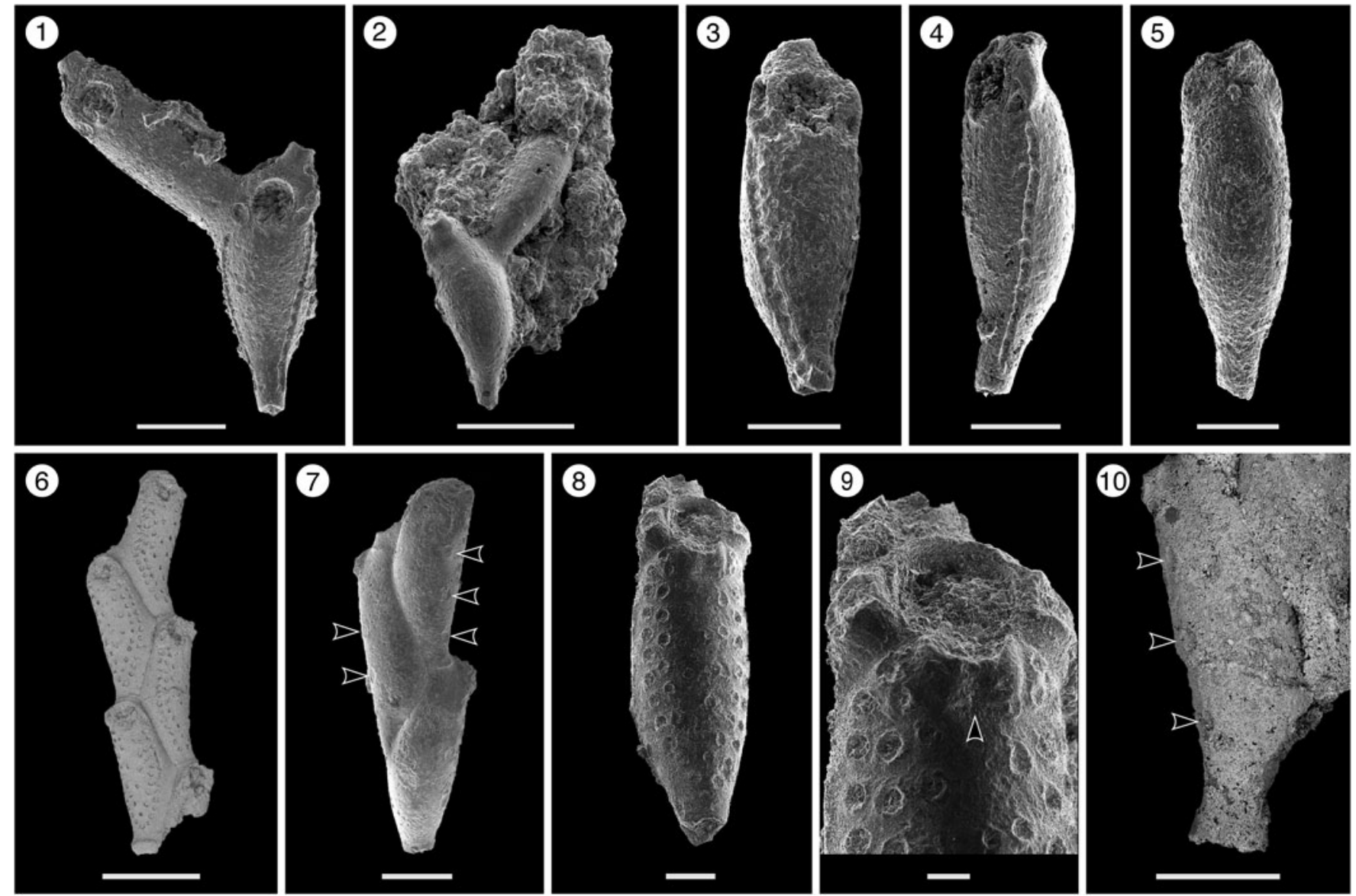

Figure 2. Catenicella sp. indet. (MUN-STRI-47666). (1) Frontal view of zooids at bifurcation, showing orifice shape, latero-oral avicularia, and location of the vittae; (2) abfrontal view of the bifurcation; (3) detail of a single zooid showing the vittae, the orifice sinus, and oral avicularia; (4) lateral view of a zooid; (5) abfrontal surface of a zooid. Ditaxiporina colombiana n. sp. (paratype MUN-STRI-47672). (6) Frontal view of a biserial internode (holotype MUN-STRI-47667); (7) abfrontal view of a biserial internode showing the lateral pores (arrowed); (8) detail of a single zooid showing the orifice shape, vestigial suboral costae, and arrangement of frontal pores; (9) detail of the orifice and the middle suture (arrowed); (10) detail of the three lateral pores (arrowed). All specimens are from the Siamaná Formation, Arroyo Ekieps locality. Scale bars are (1) $0.15 \mathrm{~mm} ;(\mathbf{2}, \mathbf{7}) 0.25 \mathrm{~mm} ;(\mathbf{3 - 5 , 8 , 1 0}) 0.1 \mathrm{~mm} ;(\mathbf{6}) 0.5 \mathrm{~mm} ;(\mathbf{9}) 0.04 \mathrm{~mm}$.

Table 1. Measurements (in mm) of Catenicella sp. indet. $\mathrm{X}=$ mean; $\mathrm{R}=$ observed range; $\mathrm{SD}=$ standard deviation; $\mathrm{N}=$ number of measurements.

\begin{tabular}{lcccr}
\hline Character & $\mathrm{X}$ & $\mathrm{R}$ & $\mathrm{SD}$ & $\mathrm{N}$ \\
\hline Autozooid length & 0.41 & $0.38-0.46$ & 0.03 & 9 \\
Autozooid width & 0.13 & $0.11-0.15$ & 0.02 & 8 \\
Orifice length & 0.07 & $0.06-0.08$ & 0.01 & 5 \\
Orifice width & 0.06 & $0.06-0.07$ & 0.01 & 4 \\
Lateral pore chamber length & 0.02 & $0.02-0.03$ & 0.01 & 9 \\
Lateral pore chamber width & 0.02 & 0.02 & 0 & 8 \\
Avicularium length & 0.06 & $0.05-0.06$ & 0.00 & 4 \\
Avicularium width & 0.03 & $0.02-0.03$ & 0.01 & 3 \\
Vittae length & 0.27 & $0.2-0.32$ & 0.03 & 11 \\
Pore vittae diameter & - & 0.01 & - & 1 \\
\hline
\end{tabular}

Remarks. - Material from the Siamaná Formation resembles the modern species Catenicella uberrima described from Indonesia, and reported from western Africa (Cook, 1968) and the western Atlantic from Florida, the Gulf of Mexico, the Caribbean, and Brazil (Winston, 1982; Ramalho et al., 2014; Delgadillo-G. and Flórez, 2015). Both species have elongate zooids and long vittae. However, C. uberrima is slightly larger, the pores of the infrascapular chambers and avicularia are placed laterally in regular zooids, and laterofrontally only in ovicellate zooids. In addition, at bifurcations, the non-articulated budded zooid is fused to the parental zooid for almost half of its length (e.g., Ramalho et al., 2014, fig. 2b), while in Catenicella sp. indet. the budded zooid is fused just at the base (Fig. 2.1). Vittaticella sp. recorded by Cheetham et al. (1999) (=Catenicella, illustrated in NMiTA Database, 1996-2016) in the Caribbean (ca. 5.9-15.7 Ma) differs from Catenicella sp. indet. in having the pore of the infrascapular chamber narrow and lanceolate, oriented proximomedially, as well as two small drop-shaped suprascapular pores, oriented almost frontally. The scarcity of material in the Siamaná Formation prevents classification at species level or the description of a new species. Catenicella sp. indet. was found in the sediment adhering to the coral Acropora panamensis (Vaughan, 1919), co-occurring with the bryozoans Licornia sp., Ditaxiporina colombiana n. sp., and Reteporellina sp. This is the oldest record of the genus Catenicella in the American continent (ca. 23-20 Ma), and the first one in coral reefs ecosystems.

\section{Genus Ditaxiporina Stach, 1935}

Type species.-Catenicella septentrionalis Waters, 1891, from Montecchio Maggiore, Italy, Priabonian (Eocene); by original designation. 
Table 2. Measurements (in mm) of Ditaxiporina colombiana $\mathrm{n}$. sp. $\mathrm{X}=$ mean; $\mathrm{R}=$ observed range; $\mathrm{SD}=$ standard deviation; $\mathrm{N}=$ number of measurements.

\begin{tabular}{lcccr}
\hline Character & $\mathrm{X}$ & $\mathrm{R}$ & $\mathrm{SD}$ & $\mathrm{N}$ \\
\hline Autozooid length & 0.71 & $0.63-0.76$ & 0.05 & 7 \\
Autozooid width & 0.26 & $0.22-0.3$ & 0.03 & 7 \\
Orifice length & 0.11 & $0.08-0.13$ & 0.02 & 5 \\
Orifice width & 0.11 & $0.1-0.12$ & 0.01 & 5 \\
Avicularium length & 0.10 & $0.09-0.1$ & 0.01 & 4 \\
Pore diameter (outer row) & 0.02 & 0.02 & 0 & 12 \\
\hline
\end{tabular}

\section{Ditaxiporina colombiana new species} Figure 2.6-2.10; Table 2

Holotype.-MUN-STRI-47667. Paratypes: MUN-STRI-47668; MUN-STRI-47669, MUN-STRI-47670, MUN-STRI-47671, MUN-STRI-47672. From the lower Miocene Siamaná Formation, Arroyo Ekieps, La Guajira, Colombia.

Diagnosis.-Colony erect, branching, uni- or biserial. Biserial internodes can be without fertile zooids. Zooids claviform. Orifice semicircular, proximal border formed by two vestigial costae. Frontal shield made of smooth gymnocyst, regularly perforated by circular pores arranged in six longitudinal rows. ?Three elliptical pores placed along each side of the zooid. Abfrontal surface smooth, lacking pores. Oral avicularia single or paired, with triangular rostrum oriented distomedially and complete crossbar. Ovicell unknown.

Description.-Colony erect, articulated, internodes uni- or biserial. Zooids elongate and claviform (mean L/W 2.76); biserial internodes with up to five zooids, alternated with and separated by narrow grooves, forming a zig-zag line along the center of the internode, all zooids facing the same side. Orifice terminal, semicircular with a broad sinus; proximal rim formed by two short and raised vestigial costae, ?with pelmata and separated by a suture along the middle line. Gymnocyst smooth, convex, perforated by circular and conspicuous pores with a slightly raised rim. Pores aligned forming three curved and concentric 'Vs'; the outer series bearing 23-27 pores; the middle series, slightly smaller, having 17-19 pores; and the inner series, the smallest, with seven pores; the central area is generally imperforate, but a small, isolated pore may occur. Three elliptical to oval lateral pores along the outer lateral side of the zooid. Abfrontal surface smooth, imperforate, and convex. Avicularia small, single or paired, placed at the sides of the orifice; rostrum triangular, short, oriented distomedially; crossbar complete. Ovicell unknown. Oral spines absent.

Etymology.-Named after Colombia, in reference to the country where it was collected for the first time, plus the Latin suffix -ianus, belonging to.

Remarks.-The analyzed material shares the characteristics of two close genera of the subfamily Ditaxiporinae Stach, 1935: the fossil genus Ditaxiporina, and the recent genus Vasignyella Gordon, 1989, the latter genus transferred to the subfamily Vasignyellinae Gordon and Braga, 1994 (Vieira et al., 2007). Both genera have species with unizooidal and/or multizooidal internodes. In the members of Vasignyella, the multizooidal internodes are infrequent and bear ovicellate zooids, the paired avicularia lack a crossbar and bear lateral pore chambers (Vieira et al., 2007, p. 51, 56). By contrast, the members of Ditaxiporina have multiserial internodes with or without fertile zooids, pelmata in the suboral costae, and single or paired avicularia with a complete crossbar (Gordon and Braga, 1994). Despite the scarcity of material and its poor preservation, it is possible to infer that the specimens belong to Ditaxiporina owing to the absence of ovicells or scars thereof in the multizooidal internodes. Two North American congeners are known from the early Oligocene, Ditaxiporina subseptentrionalis (Canu and Bassler, 1917), and Ditaxiporina bifenestrata Cheetham, 1962a. The former species differs from Ditaxiporina colombiana $\mathrm{n}$. sp. in having tubular frontal pores and in the absence of the suboral vestigial costae, while the latter species differs in having the orifice proportionately much smaller and a single smaller avicularium without crossbar (Cheetham, 1962a). The closest congener is D. septentrionalis (Waters, 1891), known from the Eocene of Italy (Gordon and Braga, 1994, fig. 10 a-d), which is similar also in the size of the autozooids; however, D. colombiana n. sp. differs in having pores in the lateral wall and three longitudinal series of frontal pores, and in the absence of a communication pore in the abfrontal surface, below the avicularia. The discovery of Ditaxiporina in the Colombian early Miocene represents the globally youngest record of the genus. In the Siamaná Formation, Ditaxiporina colombiana n. sp. was found in sediment adhering to the corals Acropora panamensis, Alveopora tampae Weisbord, 1973, and Goniopora hilli Vaughan, 1919, co-occurring with the bryozoans Licornia sp., Catenicella sp., Reteporellina sp., Margaretta cf. M. buski Harmer, 1957, Mecynoecia sp., and Poricellaria sp.

Superfamily Hippothooidea Busk, 1859

Family Trypostegidae Gordon, Tilbrook, and Winston in Winston, 2005

Genus Trypostega Levinsen, 1909

Type species. - Lepralia venusta Norman, 1864, from English Channel, Guernsey Island, Recent; by original designation.

\section{Trypostega sp. indet.}

Figure 3; Table 3

Occurrence.-Early Miocene, Siamaná Formation, Arroyo Uitpa, Colombia.

Description.-Colony encrusting, multiserial, unilaminar. Autozooids distinctly separated by narrow and shallow grooves, rhomboidal, longer than wide (mean L/W 1.64), arranged quincuncially. Frontal shield flat, evenly perforated by $46-58$ circular pseudopores (diameter $0.01 \mathrm{~mm}$ ). Orifice subterminal, pyriform to cleithridiate, longer than wide; anter semicircular, condyles seemingly robust and rounded, sinus U-shaped. Basal pore-chamber windows elliptical to circular. Zooeciules placed distally to almost each autozooid, subcircular to oval, similar in size to the primary opening of autozooids; opening small, ?circular, placed in the center or 

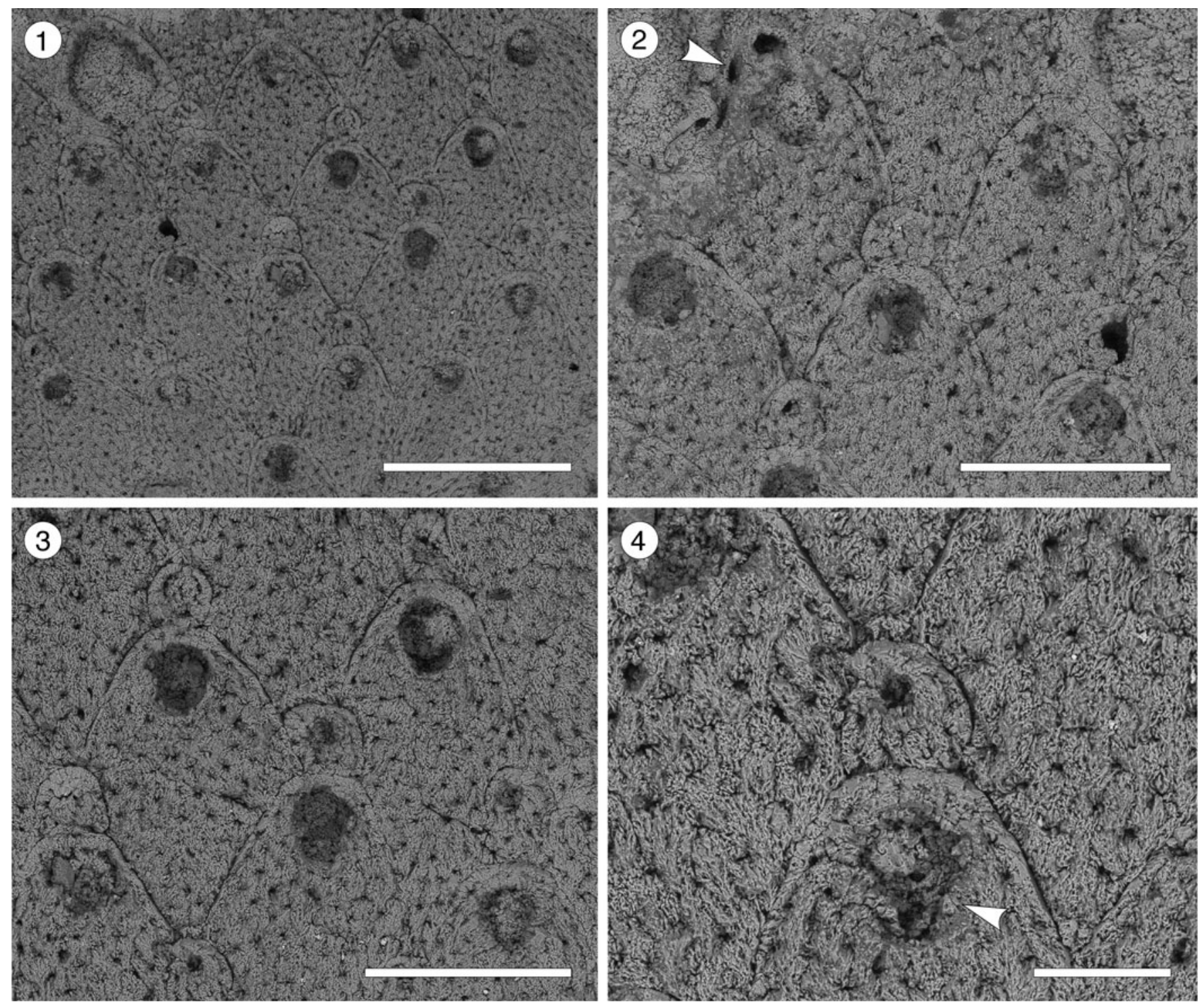

Figure 3. Trypostega sp. indet. (MUN-STRI-47675) from the Siamaná Formation, Arroyo Uitpa. (1) General view of the zooids; (2) detail of the basal porechambers (arrowed); (3) detail of the zooids and zooeciules; (4) detail of the orifice, sinus, and likely condyles (arrowed). Scale bars are (1) $0.5 \mathrm{~mm} ;(\mathbf{2}, \mathbf{3}) 0.3$ $\mathrm{mm} ;(\mathbf{4}) 0.1 \mathrm{~mm}$.

Table 3. Measurements (in $\mathrm{mm}$ ) of Trypostega sp. indet. $\mathrm{X}=$ mean; $\mathrm{R}=$ observed range; $\mathrm{SD}=$ standard deviation; $\mathrm{N}=$ number of measurements.

\begin{tabular}{lcccr}
\hline Character & $\mathrm{X}$ & $\mathrm{R}$ & $\mathrm{SD}$ & $\mathrm{N}$ \\
\hline Autozooid length & 0.47 & $0.41-0.55$ & 0.04 & 21 \\
Autozooid width & 0.29 & $0.24-0.35$ & 0.03 & 21 \\
Orifice length & 0.09 & $0.08-0.11$ & 0.01 & 13 \\
Orifice width & 0.08 & $0.07-0.09$ & 0.01 & 13 \\
Zooeciules length & 0.09 & $0.07-0.13$ & 0.01 & 20 \\
Zooeciules width & 0.10 & $0.07-0.12$ & 0.01 & 20 \\
Zooeciular opesia length & 0.03 & $0.03-0.04$ & 0.01 & 4 \\
Zooeciular opesia width & 0.03 & $0.02-0.05$ & 0.01 & 4 \\
\hline
\end{tabular}

slightly displaced distally; frontal shield flat, evenly covered by circular pseudopores as in autozooids. Suboral umbo absent. Ovicells not observed.

Remarks.-Despite the high level of recrystallization in the single specimen available, the key features of the genus
Trypostega, such as the presence of zooeciules, cleithridiate orifice, and the pseudoporous pattern of the frontal shield, are clearly distinguishable. Five fossil species of this genus are known from North America: T. inornata (Gabb and Horn, 1862), T. elongata Canu and Bassler, 1920, and T. undulata (Canu and Bassler, 1920) from the Eocene; T. vokesi Di Martino, Taylor, and Portell, 2017, from the Miocene (Burdigalian); and T. composita Di Martino, Taylor, and Portell, 2019, from the Pliocene (Piacenzian). Trypostega inornata and $T$. elongata both resemble $T$. sp. indet. in having zooeciules associated to each autozooid, but the former species differs in having zooids with an imperforate frontal shield, while the latter species differs in having elongate and fusiform zooeciules. Trypostega composita differs in having zooeciules of variable size and shape, often forming clusters, in addition to frontal subcolonies. The remaining species differ in having a suboral umbo that is constantly present or at 
least developed in some areas of the colony (e.g., T. vokesi). Among Recent West Atlantic species, T. striatula (Smitt, 1873), T. ilhabelae Winston and Vieira, 2013, and T. tropicalis Winston, Vieira, and Woollacott, 2014, all differ in having a suboral umbo, and T. striatula also has longitudinal, conspicuous striations. The absence of ovicells and scarcity of specimens prevent a new species introduction. In the Siamaná Formation Trypostega sp. indet. was found growing on Porites sp., co-occurring with an indeterminate cheilostome.

Superfamily Arachnopusioidea Jullien, 1888

Family Arachnopusiidae Jullien, 1888 Genus Poricella Canu, 1904

Type species.—Poricella maconnica Canu, 1904, from Tunisia, Eocene; by original designation.

\section{Poricella paulae new species Figure 4; Table 4}

Holotype.-MUN-STRI-47676. Paratypes: MUN-STRI-47677, MUN-STRI-47678, MUN-STRI-47679, MUN-STRI-47680, MUN-STRI-47681. From the lower Miocene Siamaná Formation, Arroyo Ekieps, La Guajira Colombia.

Diagnosis. - Colony encrusting. Autozooids distinct, ovoidal to elliptical. Orifice terminal, semicircular, slightly wider proximally; four to six oral spine bases. Frontal shield smooth, convex, perforated by 3-9 (most often 7) foramina; suboral mucro present or absent. One to three prominent, interzooidal avicularia surrounding each autozooid, usually rounded to elliptical or subspatulate. Sparse giant interzooidal avicularia, with elliptical or pyriform opesia and rounded rostrum. All avicularia lacking crossbar. Ovicell hyperstomial, globular.

Description.-Colony encrusting, multiserial, multilaminar. Autozooids distinct, separated by deep furrows, ovoidal to elliptical (mean L/W 1.39), arranged in alternating rows or irregularly. Frontal shield convex with a relatively flat center, smooth, perforated by 3-9, most often seven, circular or bean-shaped foramina of different sizes; suboral mucro developed in most zooids. Marginal areolar pores few and small. Pore-chamber windows large, circular to elliptical, visible in the lateral and distal walls of marginal zooids. Orifice terminal, D-shaped; two rounded, proximally placed condyles separating a semicircular anter from a slightly wider sinus with straight to slightly concave proximal border; 4-6 oral spine bases. One to three interzooidal avicularia placed mid-lateral or distolateral to each zooid, variable in shape and size, mainly oval, sporadically subspatulate, prominent, with short rostrum oriented distally or distolaterally. Giant interzooidal avicularia less frequent, with long, straight, parallel sided, rounded rostrum and pyriform to elliptical opesia. Crossbar not observed. Ovicell hyperstomial, globular and imperforate.

Etymology.-Named after researcher Paula Zapata-Ramírez (Universidad Pontificia Bolivariana), who obtained funds to undertake research on the Siamaná Formation coral reefs and collected the coral samples in 2011.
Remarks.-Three fossil species and a population group of Poricella are known from southern North America and the Caribbean: P. horrida (Canu and Bassler, 1923) from the Miocene of Florida, P. lidgardi (Taylor and Foster, 1994) from the Plio-Pleistocene of Tobago, P. mucronata (Smitt, 1873) from the Miocene to Recent of Gulf of Mexico and Caribbean, and 'Poricella miocenica' (McGuirt, 1941), originally described from the middle Miocene of Louisiana, and subsequently found in the middle Miocene of Florida and South Carolina (Cook, 1977). Poricella horrida is easily distinguishable from $P$. paulae $\mathrm{n}$. sp. in having an elongate orifice with condyles very close to the proximal border, and large interzooidal avicularia with triangular rostrum, single foramen, and conspicuous marginal areolar pores. Poricella lidgardi differs from the new species in having 1-3 foramina, adjacent zooids connected by calcified buttresses, and in the lack of condyles, oral spines, and mucro. Poricella mucronata exhibits a significant variation in the number of frontal foramina and oral spines, in the presence/absence of the suboral mucro, and in the shape and size of avicularia (Powell and Cook, 1967; Cook, 1977; Di Martino et al., 2017). However, some features appear to be more dominant than others, such as avicularia with truncate rostra and distal expansion, reduced number of foramina (generally three and always fewer than six), and almost equidimensional orifice. Although 'Poricella miocenica' is closely related to P. mucronata, Cook (1977, p. 131) distinguished the former species based on its similarity with Miocene species from Africa and Europe. Poricella paulae n. sp. resembles ' $P$. miocenica' sensu Cook (1977) in having avicularia associated with the ovicell, in the size of the orifice, and the frequency and orientation of oval/elliptical avicularia. However, it differs in the greater number of foramina (3-9 versus 1-2), and in the broader variety of interzooidal avicularia. Among Miocene European congeners, Poricella paulae n. sp. shares some features with $P$. areolata (Reuss, 1874) from Austria (on the coral Porites incrustans) and P. pouyetae (Cook, 1977) from France. Both these species have elongate orifices, and $P$. pouyetae also shows conspicuous marginal areolar pores. In addition, $P$. areolata bears a single foramen, and despite $P$. pouyetae bearing seven foramina, as does $P$. paulae n. sp., these are located more centrally on the frontal shield. In the Siamaná Formation, Poricella paulae n. sp. was found growing on the corals Alveopora tampae, Acropora panamensis, Millepora sp., and Caryophylliidae, co-occurring with Hippopodina sp. indet., Cribrilaria multicostata Flórez, Di Martino, and Ramalho, 2021, Hippopleurifera sp. indet. 2, and an indeterminate cheilostome.

Arachnopusiidae gen. and sp. indet. Figure 5; Table 5

Occurrence.-Early Miocene, Siamaná Formation, Arroyo Ekieps, Colombia.

Description.-Colony encrusting, multiserial, uni- to multilaminar. Autozooids distinctly separated by deep furrows, elliptical to rounded hexagonal, longer than wide (mean L/W 1.34), irregularly arranged. Frontal shield 

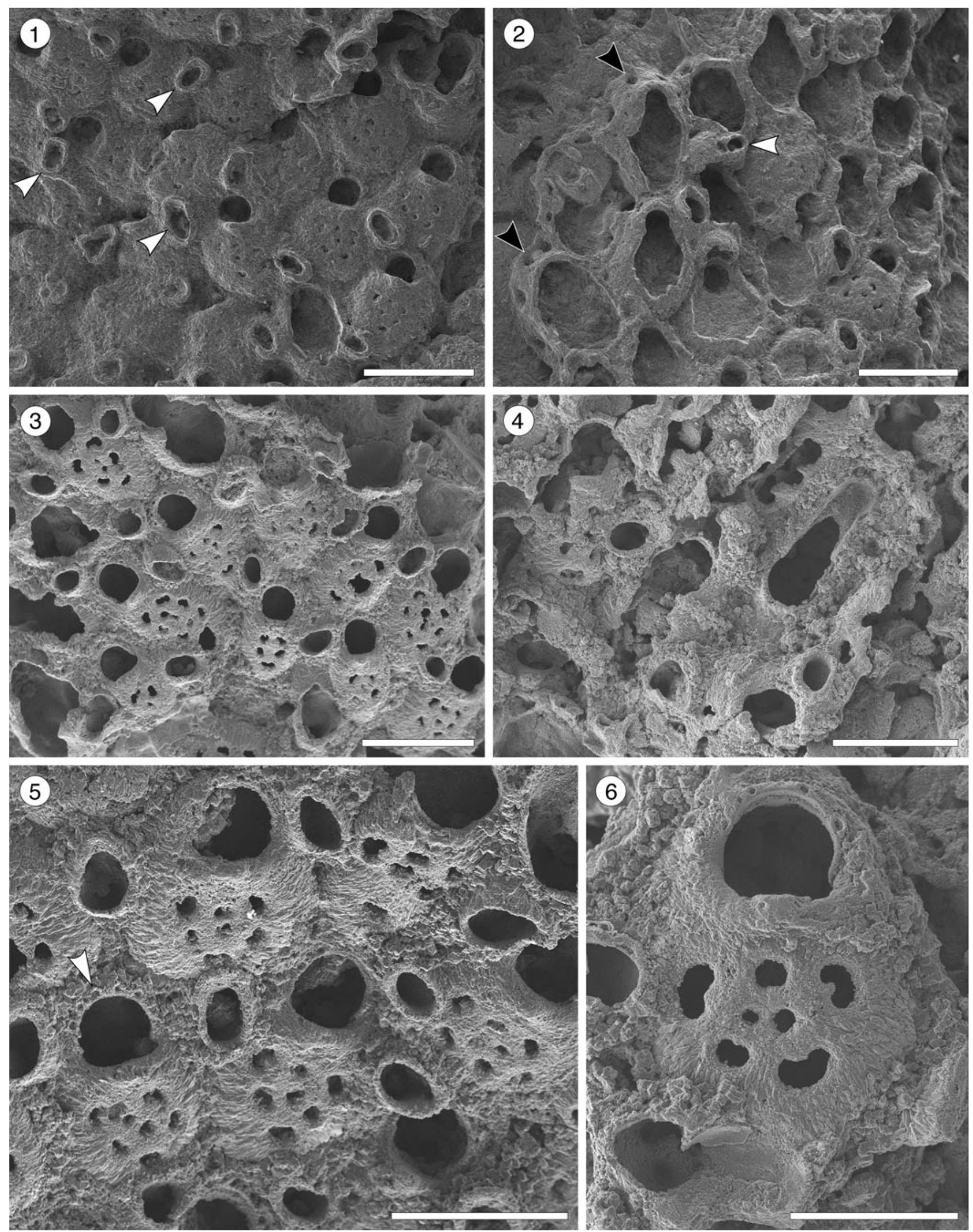

Figure 4. Poricella paulae n. sp. (paratype MUN-STRI-47680) from the Siamaná Formation, Arroyo Ekieps. (1) General view of the colony with several subspatulate avicularia (arrowed); (2) detail of the pore-chambers (black arrows) and avicularium associated with the ovicell (white arrow); (holotype MUN-STRI-47676) (3) general view of the zooids and rounded interzooidal avicularia; $(\mathbf{4})$ detail of the giant elongate interzooidal avicularium; $\mathbf{( 5 )}$ detail of the orifice bearing six oral spines (arrowed); (6) detail of the frontal foramina, orifice with condyles, and interzooidal avicularium. Scale bars are (1-4) $0.5 \mathrm{~mm} ;(\mathbf{5}) 0.4 \mathrm{~mm} ;(\mathbf{6}) 0.3 \mathrm{~mm}$. 
Table 4. Measurements (in $\mathrm{mm}$ ) of Poricella paulae $\mathrm{n}$. $\mathrm{sp}$. $\mathrm{X}=$ mean; $\mathrm{R}=$ observed range; $\mathrm{SD}=$ standard deviation; $\mathrm{N}=$ number of measurements.

\begin{tabular}{lcccr}
\hline Character & $\mathrm{X}$ & $\mathrm{R}$ & $\mathrm{SD}$ & $\mathrm{N}$ \\
\hline Autozooid length & 0.56 & $0.43-0.72$ & 0.07 & 36 \\
Autozooid width & 0.40 & $0.24-0.62$ & 0.09 & 31 \\
Orifice length & 0.15 & $0.11-0.18$ & 0.02 & 26 \\
Orifice width & 0.16 & $0.14-0.19$ & 0.01 & 24 \\
Oval avicularium length & 0.20 & $0.16-0.26$ & 0.02 & 19 \\
Oval avicularium width & 0.13 & $0.1-0.19$ & 0.02 & 19 \\
Oval avicularian opesia length & 0.13 & $0.1-0.15$ & 0.02 & 15 \\
Oval avicularian opesia width & 0.09 & $0.07-0.11$ & 0.01 & 15 \\
Spatulate avicularium length & 0.22 & $0.19-0.24$ & 0.02 & 4 \\
Spatulate avicularium width & 0.14 & $0.13-0.14$ & 0.01 & 4 \\
Spatulate avicularian opesia length & 0.13 & $0.11-0.14$ & 0.02 & 2 \\
Spatulate avicularian opesia width & 0.08 & 0.08 & 0 & 3 \\
Large avicularium length & 0.40 & $0.38-0.42$ & 0.03 & 2 \\
Large avicularium width & 0.16 & $0.14-0.17$ & 0.02 & 2 \\
Large avicularian opesia length & 0.47 & $0.37-0.64$ & 0.13 & 4 \\
Large avicularian opesia width & 0.21 & $0.18-0.23$ & 0.02 & 4 \\
Ooecium length & 0.16 & $0.14-0.17$ & 0.02 & 4 \\
Ooecium width & 0.22 & $0.18-0.27$ & 0.05 & 3 \\
Foramen diameter & 0.05 & $0.03-0.1$ & 0.03 & 12 \\
\hline
\end{tabular}

cryptocystal, convex, perforated by 16-18 rounded to elliptical foramina $(0.03 \mathrm{~mm})$; marginal areolar pores subcircular to slit-like, wider at zooidal corners $(0.10 \times 0.05 \mathrm{~mm})$; one or two large, elliptical to drop-shaped, pore-chamber windows. Orifice subcircular; a horseshoe-shaped anter separated from a slightly wider, shallow sinus by two blunt condyles; six oral spine bases in non-ovicellate zooids, four in ovicellate zooids, the proximalmost pair seemingly larger in diameter $(\sim 0.030$ vs. $0.028 \mathrm{~mm}$ ). Single, adventitious avicularium placed lateral to the orifice, triangular, oriented distally, apparently without crossbar. Interzooidal avicularia infrequent, oval, located lateral to the autozooids. Ovicells hyperstomial, subglobular; ectooecium poorly preserved, endooecium seemingly largely exposed, smooth.

Remarks.-We place this specimen in the family Arachnopusiidae because of the relatively large size of the frontal surface foramina, the presence of oral spines and basal pore chambers, and the prominent ovicells (Gordon, 1984, p. 68). Among the genera of this family, it resembles Arachnopusia Jullien, 1888, in having recumbent ovicells with a frontal window exposing the endooecium; however, it differs in having autozooids with distinct outline, foramina lacking a ligula, and in the absence of suboral avicularia (Hayward and Thorpe, 1988). It also resembles Briarachnia Gordon, 1984, in having exposed endooecium, but Briarachnia lacks interzooidal avicularia. The poor preservation of the single specimen found in the Siamaná Formation prevents description of a new genus or species. Arachnopusiidae sp. indet. was found encrusting the coral Porites baracoaensis Vaughan, 1919.

Superfamily Lepralielloidea Vigneaux, 1949

Family Romancheinidae Jullien, 1888

Genus Escharoides Milne-Edwards, 1836

Type species.-Cellepora coccinea Abildgaard, 1806, from Helgoland, North Sea, Recent; by original designation.

Escharoides aff. E. martae Marcus, 1955

Figure 6; Table 6 aff. 1955 Escharoides martae Marcus, p. 299, figs. 56, 57.

Holotype.-Lost, from South of Vitória, Espírito Santo State, at $35 \mathrm{~m}$ depth, Brazil. Recent.

Occurrence.-Early Miocene, Siamaná Formation, Arroyo Uitpa, Colombia.

Description.-Colony encrusting, multiserial, unilaminar. Autozooids distinct, separated by deep grooves, oval to polygonal, slightly longer than wide (mean L/W 1.27). Frontal shield slightly convex, smooth, centrally imperforate, surrounded by a single row of circular marginal areolar pores separated by ridges. Orifice terminal, semicircular distally, hidden by the peristome proximally. Peristomial aperture shallow, two proximal sinuses formed by two robust, rounded, lateral denticles and a central ridge, bearing distally 6-7 oral spine bases $(0.03 \mathrm{~mm}$ in diameter). Adventitious avicularia single or paired, similar in size, placed on raised, well-developed cystids outlined by a row of marginal areolar pores, located laterally adjacent to zooidal margins, at about half zooidal length; when paired, one placed more proximally than the other; rostrum triangular, oriented proximolaterally and obliquely to the frontal shield plane, crossbar complete. Ovicells not observed.

Remarks.-Canu and Bassler (1920) introduced (as Peristomella) the species Escharoides falcifera and E. laticella from the Eocene, and E. erecta from the Oligocene of North America. Cheetham, Sanner, and Jackson (2007) described E. guraboensis from the late Miocene-early Pliocene, and Osburn (1914) described E. costifer from the late PlioceneRecent of the Caribbean region. All of these species differ from Escharoides aff. E. martae in the position and orientation of the lateral avicularia, which are placed more distally and closer to the orifice and are directed laterally, distally or distolaterally. Although these fossil specimens closely resemble the Recent E. martae from Brazil in the location, shape, and direction of the avicularia and size of autozooids, the nominal species has a more developed peristome lacking a central ridge, sparse and prominent calcified granules on the frontal shield, and larger avicularia; in addition, the mean of zooidal length/zooidal width ratio of our specimens is lower than in the Recent material (1.27 vs. 1.60). Even though E. aff. E. martae may have lost the ornament of the frontal shield by dissolution or mechanical abrasion, as seen in other Escharoides species (Berning, 2006), the preserved morphology of the peristome distinguishes it from the nominal species. The absence of ovicells discouraged creation of a new species. In the Siamaná Formation, E. aff. E. martae was found encrusting rubble of Porites sp., sharing the substrate with Gymnophorella hadra Flórez, Di Martino, and Ramalho, 2021, and poorly preserved, indeterminate cribrilinids.

Genus Hippomenella Canu and Bassler, 1917

Type species.-Lepralia mucronelliformis Waters, 1899, from Madeira, Atlantic Ocean, Recent; by original designation. 

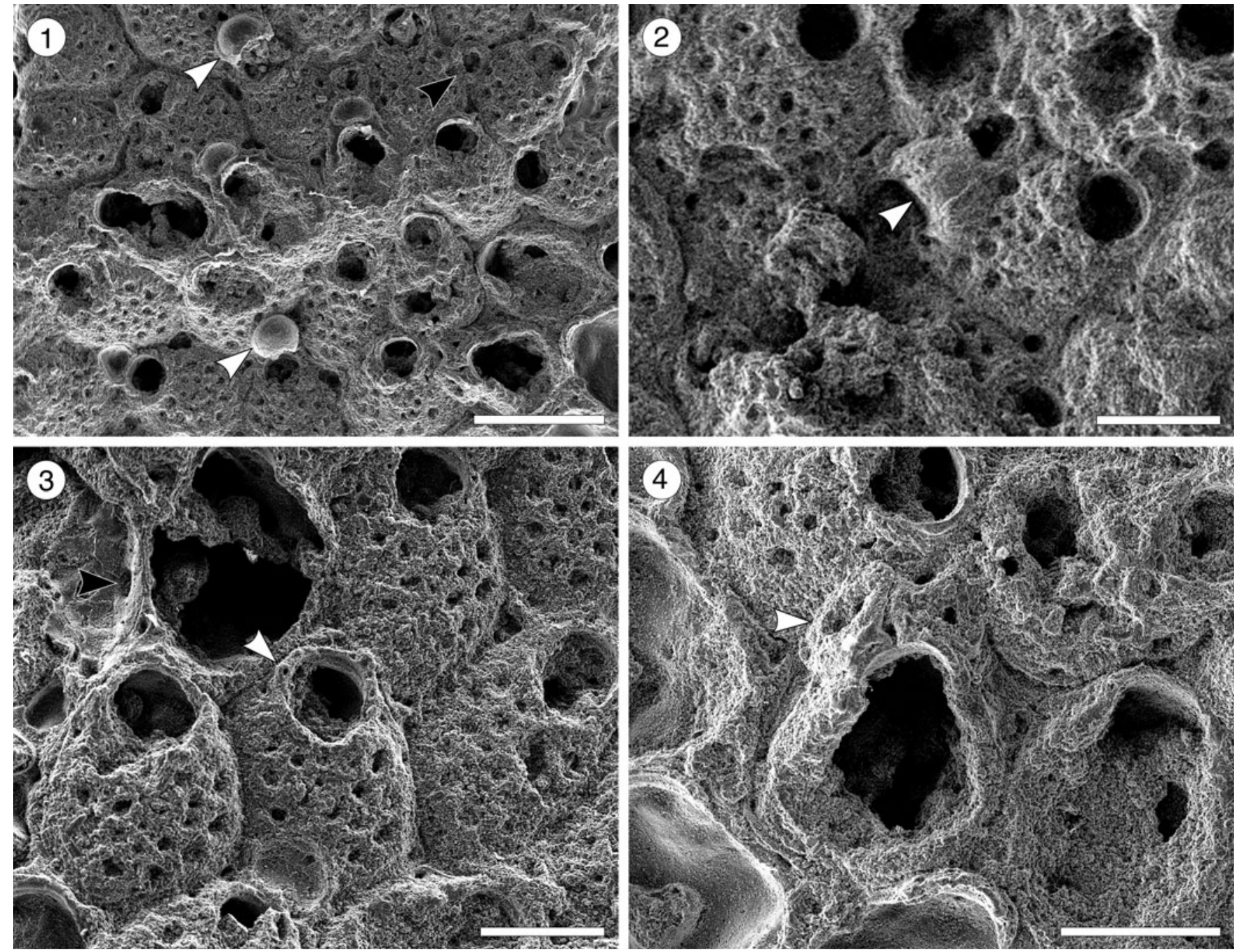

Figure 5. Arachnopusiidae gen. et sp. indet. (MUN-STRI-47682) from the Siamaná Formation, Arroyo Ekieps. (1) Fertile zooids with incomplete ectooecium exposing the smooth endooecium (white arrows), and rounded interzooidal avicularium (black arrow); (2) detail of the ovicell with the frontal window exposing the smooth endooecium (arrowed); (3) detail of the zooids showing the basal pore-chambers (black arrow) and oral spine bases (white arrow); (4) detail of the triangular adventitious avicularium (arrowed). Scale bars are $0.25 \mathrm{~mm}$.

Remarks. - The definition of this genus has been puzzling since its introduction in 1917 (Tilbrook, 2006, p. 257; Berning, 2013, p. 8; Ramalho et al., 2015, p. 126). The absence of ovicell description in the original diagnosis of Hippomenella has led over the years to the inclusion in this genus of species with

Table 5. Measurements (in mm) of Arachnopusiidae gen. et sp. indet. $X=$ mean; $\mathrm{R}=$ observed range; $\mathrm{SD}=$ standard deviation; $\mathrm{N}=$ number of measurements.

\begin{tabular}{lcccr}
\hline Character & X & \multicolumn{1}{c}{$\mathrm{R}$} & $\mathrm{SD}$ & $\mathrm{N}$ \\
\hline Autozooid length & 0.49 & $0.4-0.58$ & 0.04 & 28 \\
Autozooid width & 0.37 & $0.31-0.42$ & 0.03 & 26 \\
Orifice length & 0.13 & $0.13-0.14$ & 0.01 & 3 \\
Orifice width & 0.15 & $0.14-0.16$ & 0.01 & 3 \\
Oval avicularium length & 0.16 & 0.16 & 0 & 2 \\
Oval avicularium width & 0.14 & $0.13-0.15$ & 0.01 & 2 \\
Triangular avicularium length & - & 0.21 & - & 1 \\
Triangular avicularium width & - & 0.1 & - & 1 \\
Ooecium length & 0.13 & $0.1-0.14$ & 0.02 & 6 \\
Ooecium width & 0.18 & $0.15-0.22$ & 0.03 & 6 \\
Pore diameter & 0.03 & $0.02-0.03$ & 0 & 10 \\
\hline
\end{tabular}

bifenestrate ectooecium, a diagnostic feature of Hippopleurifera (Berning, 2013). In addition, discovery of fossil specimens exhibiting a combination of characters of the two genera (Di Martino and Taylor, 2015, p. 18), as in the material from the Siamaná Formation, increases the uncertainty. Here, we follow the amended diagnosis of Hippomenella in Berning (2013), and provide an open classification for three species: one placed in Hippomenella (based on a wider umbonuloid area, up to six oral spines, and adventitious avicularia) and two in Hippopleurifera (based on a reduced umbonuloid area, more than seven oral spines, and ovicells with bifenestrate ectooecium).

\section{Hippomenella sp. indet.} Figure 7; Table 7

Occurrence.-Early Miocene, Siamaná Formation, Arroyo Ekieps, Colombia. 

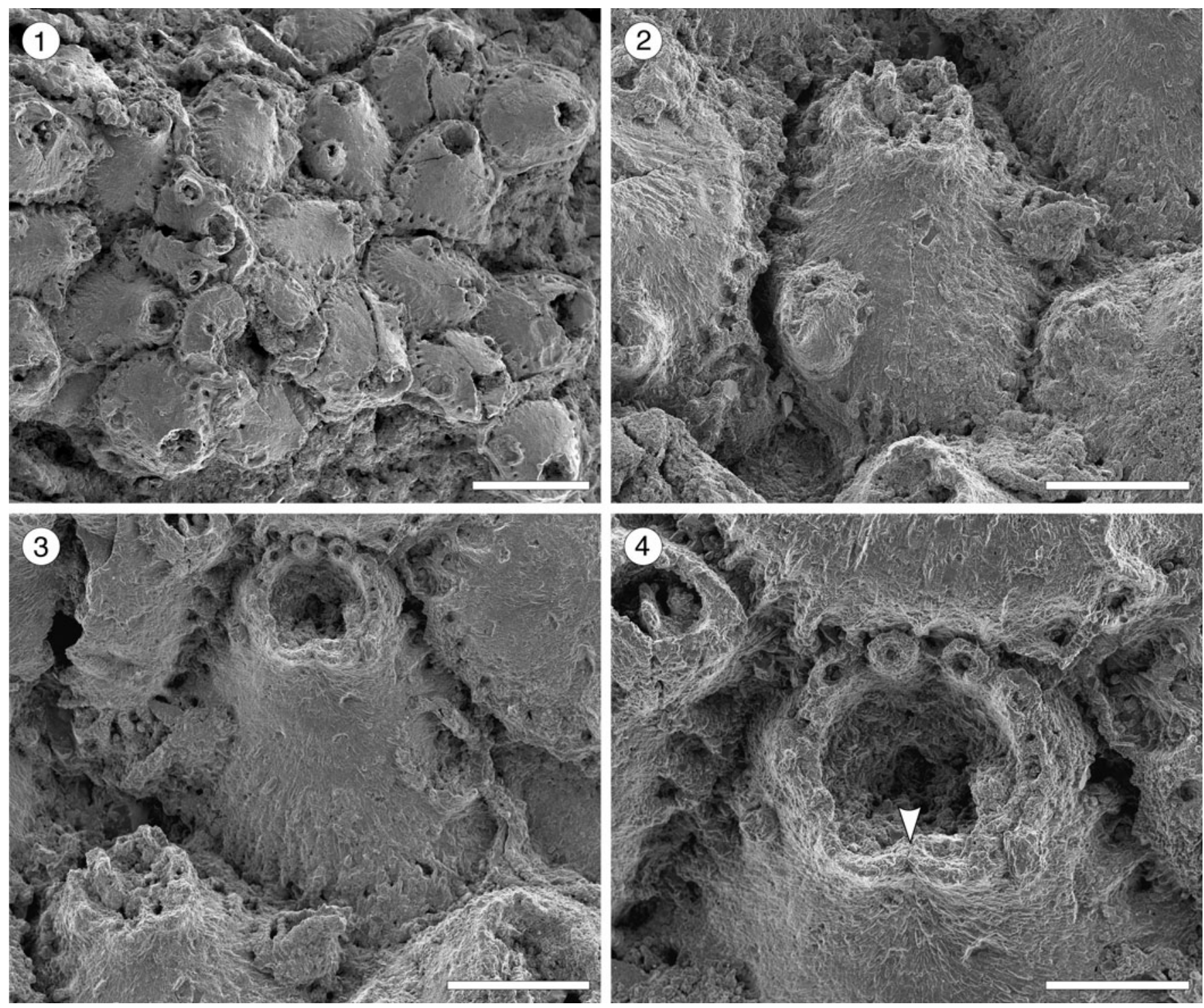

Figure 6. Escharoides aff. E. martae Marcus, 1955 (MUN-STRI-47683) from the Siamaná Formation, Arroyo Uitpa. (1) General view of the colony; (2) detail of a zooid and its avicularia; (3) detail of the peristomial aperture; (4) detail of the secondary orifice, central denticle (arrowed), and oral spine bases. Scale bars are (1) 0.5 $\mathrm{mm} ;(\mathbf{2}, \mathbf{3}) 0.2 \mathrm{~mm} ;(\mathbf{4}) 0.1 \mathrm{~mm}$.

Description.-Colony encrusting, multiserial, uni- to multilaminar. Autozooids separated by deep grooves, rhomboidal to claviform, longer than wide (mean L/W 1.35). Frontal shield slightly depressed marginally, raised suborally, imperforate except for 2-3 rows of elliptical, marginal areolar pores $(0.03-0.04 \mathrm{~mm}$ in length) with radially arranged ridges in between. Orifice subcircular with straight to slightly convex

Table 6. Measurements (in mm) of Escharoides aff. E. martae. $\mathrm{X}=$ mean; $\mathrm{R}=$ observed range; $\mathrm{SD}=$ standard deviation; $\mathrm{N}=$ number of measurements.

\begin{tabular}{lcccr}
\hline Character & X & R & SD & N \\
\hline Autozooid length & 0.56 & $0.49-0.63$ & 0.04 & 12 \\
Autozooid width & 0.44 & $0.4-0.49$ & 0.03 & 10 \\
Orifice length & 3.09 & $0.1-12$ & 5.94 & 4 \\
Orifice width & 0.15 & $0.14-0.16$ & 0.01 & 4 \\
Avicularium length & 0.14 & $0.12-0.15$ & 0.01 & 5 \\
Avicularium width & 0.09 & $0.08-0.09$ & 0.01 & 3 \\
Avicularian cystid length & 0.11 & $0.1-0.11$ & 0.01 & 2 \\
\hline
\end{tabular}

proximal border; four distal oral spine bases in non-ovicellate zooids, at least two visible in ovicellate zooids. Adventitious avicularia dimorphic; a small avicularium, generally poorly preserved, placed suborally on a raised umbo; larger, distolateral avicularia placed next to the orifice, at level with the orifice proximal margin or slightly above, with triangular rostrum, oriented distolaterally and inwards, sometimes bending over the orifice. Ovicells hyperstomial, globular, surface granular.

Remarks.-Our specimens consist of small colony fragments, each with only a few poorly preserved autozooids. We placed them into the genus Hippomenella based on the wide area of imperforate frontal shield, the presence of suboral and lateral avicularia, and the number of oral spines. Canu and Bassler (1920) introduced the species Hippomenella transversora and ?Hippomenella pungens from the North American Oligocene; Hippomenella sp. indet. resembles both species in general appearance. However, H. tranversora has up to six oral 

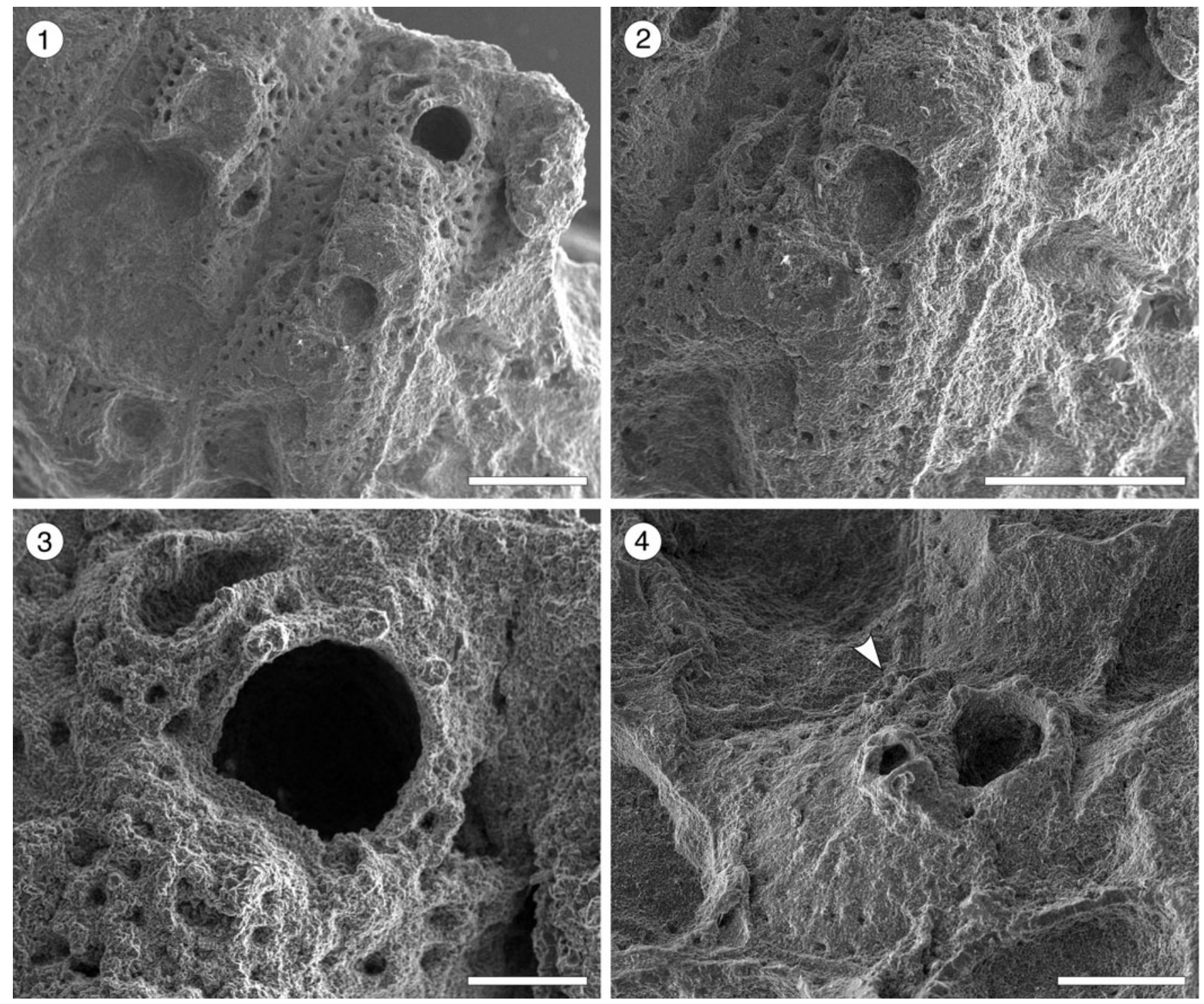

Figure 7. Hippomenella sp. indet. from the Siamaná Formation, Arroyo Ekieps. (MUN-STRI-47698) (1) general view of the zooids; (2) detail of the ooecium; (3) detail of the orifice, oral spine bases, and avicularia; (MUN-STRI-47697) (4) detail of the suboral avicularia, oral spine bases, and lateral avicularia (arrowed). Scale bars are (1, 2) $0.5 \mathrm{~mm} ;(\mathbf{3}) 0.15 \mathrm{~mm} ;(\mathbf{4}) 0.25 \mathrm{~mm}$.

spines, ooecium with an elongate pore, a small, triangular avicularium transversally directed, and lacks suboral avicularia, while ?H. pungens has two symmetrical avicularia placed below the level of the orifice.

Canu and Bassler (1920) also described seven species of ?Hippomenella from the North American Eocene, among

Table 7. Measurements (in mm) of Hippomenella sp. indet. $\mathrm{X}=$ mean; $\mathrm{R}=$ observed range; $\mathrm{SD}=$ standard deviation; $\mathrm{N}=$ number of measurements.

\begin{tabular}{lcllr}
\hline Character & $\mathrm{X}$ & \multicolumn{1}{c}{$\mathrm{R}$} & $\mathrm{SD}$ & $\mathrm{N}$ \\
\hline Autozooid length & 0.83 & $0.65-1$ & 0.10 & 14 \\
Autozooid width & 0.61 & $0.43-0.89$ & 0.12 & 20 \\
Orifice length & 0.20 & $0.19-0.22$ & 0.02 & 3 \\
Orifice width & 0.22 & $0.20-0.23$ & 0.01 & 4 \\
Lateral avicularium length & 0.29 & $0.19-0.34$ & 0.06 & 5 \\
Lateral avicularium width & 0.15 & 0.15 & 0 & 3 \\
Ooecium length & - & 0.36 & - & 1 \\
Ooecium width & 0.43 & $0.42-0.44$ & 0.01 & 2 \\
\hline
\end{tabular}

which Hippomenella sp. indet. resembles ?H. punctata in the suboral placement of the avicularia, but lacks the larger avicularium placed laterally to the orifice. ?Hippomenella infratelum Canu and Bassler, 1919, known from the Caribbean early Miocene, lacks oral spines and differs from Hippomenella sp. indet. also in having an elliptical avicularium with a complete crossbar placed more proximally on the autozooid. In the Siamaná Formation, Hippomenella sp. indet. was found on the corals Caryophylliidae and Acropora sp., co-occurring with Figularia bragai Flórez, Di Martino, and Ramalho, 2021, Hippopleurifera sp. indet. 2, Gemelliporidra aff. G. magniporosa, and an indeterminate cribrilinid.

\section{Genus Hippopleurifera Canu and Bassler, 1925}

Type species.-Eschara biauriculata Reuss, 1847, from Eisenstadt, Mörbisch, and Kroisbach (Austria), and Oedenburg (Hungary), Miocene; by original designation. 

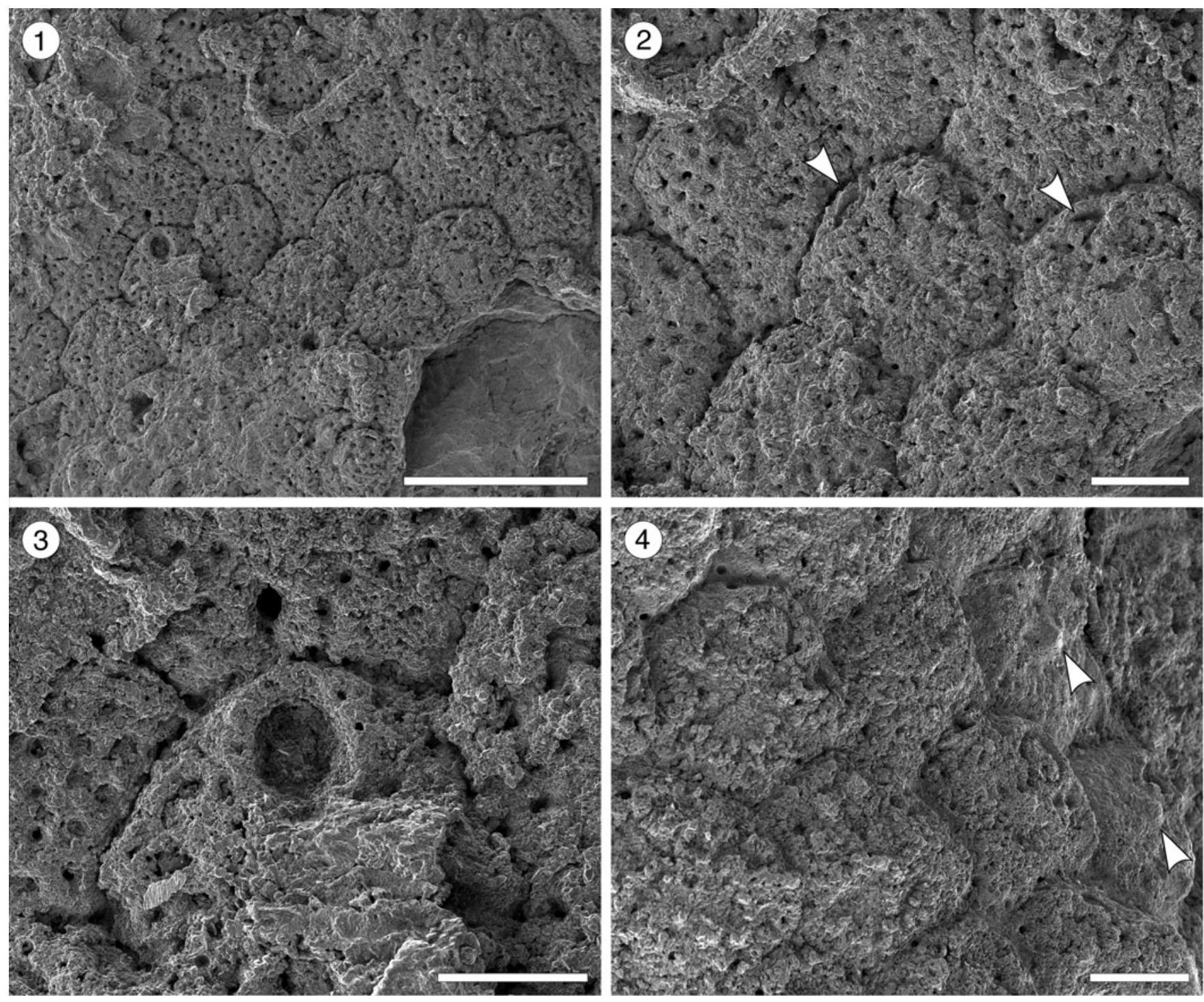

Figure 8. Hippopleurifera aff. H. mucronata (Smitt, 1873) from the Siamaná Formation, Arroyo Uitpa. (MUN-STRI-47693) (1) general view of the colony; (2) detail of the zooids and avicularia (arrowed); (3) detail of the orifice showing the U-shaped sinus and oral spine bases; (4) zooids showing the suboral umbo (arrowed). Scale bars are (1) $1 \mathrm{~mm} ;(\mathbf{2}, \mathbf{4}) 0.25 \mathrm{~mm} ;(\mathbf{3}) 0.2 \mathrm{~mm}$.

Hippopleurifera aff. H. mucronata (Smitt, 1873) Figure 8; Table 8

aff. 2005 Hippopleurifera mucronata; Winston, p. 54, figs. 143-145.

aff. 2017 Hippopleurifera mucronata; Di Martino et al., p. 151, fig. $41 \mathrm{a}-\mathrm{d}$.

aff. 2019 Hippopleurifera mucronata; Di Martino et al., p. 31, fig. 26.

Table 8. Measurements (in mm) of Hippopleurifera aff. H. mucronata. $\mathrm{X}=$ mean; $\mathrm{R}=$ observed range; $\mathrm{SD}=$ standard deviation; $\mathrm{N}=$ number of measurements.

\begin{tabular}{lcccr}
\hline Character & $\mathrm{X}$ & $\mathrm{R}$ & $\mathrm{SD}$ & $\mathrm{N}$ \\
\hline Autozooid length & 0.59 & $0.46-0.69$ & 0.06 & 13 \\
Autozooid width & 0.56 & $0.45-0.65$ & 0.07 & 10 \\
Orifice length & 0.16 & $0.15-0.16$ & 0.01 & 2 \\
Orifice width & 0.12 & $0.11-0.13$ & 0.01 & 8 \\
Avicularium length & 0.20 & $0.19-0.21$ & 0.01 & 2 \\
\hline
\end{tabular}

Syntype.-MCZ 22, Smitt collection, from Florida, at $53 \mathrm{~m}$ depth, USA. Recent (Winston, 2005).

Occurrence.-Early Miocene, Siamaná Formation, Arroyo Uitpa, Colombia.

Description.-Colony encrusting, multiserial, unilaminar. Autozooids distinctly separated by narrow and deep grooves, rhomboidal, claviform, or hexagonal, almost as long as wide (mean L/W 1.05). Frontal shield convex, ribbed, with 2-3 rows of marginal areolar pores, evenly spaced, subcircular $(0.02$ $0.03 \mathrm{~mm}$ in diameter), imperforate central area reduced. Orifice with semielliptical anter and narrow, U-shaped sinus; condyles not preserved; pointed suboral umbo poorly preserved; six distolateral oral spine bases. Adventitious avicularia infrequent, placed at about the same level of the oral sinus, near and parallel to zooidal margins; rostrum triangular, narrow, oriented proximolaterally; crossbar not preserved. Ovicells not observed. 
Remarks. - The poorly preserved specimen available resembles the nominal species Hippopleurifera mucronata in shape of the orifice, number of oral spines, multiple rows of marginal areolar pores, and position and shape of the avicularia. Compared to other records of $H$. mucronata, the Colombian material differs in the position and orientation of avicularia (e.g., in Di Martino et al., 2017, fig. 41a, d, the avicularium is directed almost transversally), and in the extension of the imperforate area of frontal shield (e.g., in both Winston, 2005, fig. 143, and Di Martino et al., 2017, the imperforate area is larger). This latter character also distinguishes $H$. aff. $H$. mucronata from the North American Oligocene H. capitimortis Canu and Bassler, 1920, and H. ampla Canu and Bassler, 1920. In the Siamaná Formation, $H$. aff. $H$. mucronata was found encrusting rubble of the coral Porites sp. and coralline algae, co-occurring with Smittipora sp. indet. (Flórez et al., 2021) and Trypostega sp. indet.

\section{Hippopleurifera sp. indet. 1} Figure 9; Table 9

Occurrence.-Early Miocene, Siamaná Formation, Arroyo Uitpa and Flor de La Guajira, Colombia.

Description.-Colony encrusting, multiserial, unilaminar. Autozooids distinctly separated by deep grooves, elliptical to subhexagonal, slightly longer than wide (mean L/W 1.22). Frontal shield slightly convex, central U-shaped area imperforate, flanked by 3-4 rows of circular, elliptical, or drop-shaped areolar pores $(0.04 \mathrm{~mm}$ long $\times 0.03 \mathrm{~mm}$ wide $)$ sloping inwards and separated by ridges. Orifice slightly longer than wide with arched anter separated from a smaller concave poster by two blunt condyles; $8-10$ distolateral oral spine bases in non-ovicellate zooids, four in ovicellate zooids; suboral peristome well developed. Adventitious avicularia present or absent, one or two; one placed on the lateral margin of the zooid among the rows of areolar pores at about the same level of the orifice condyles, with triangular rostrum oriented laterally to proximolaterally, crossbar complete; in about half of the zooids, a second, smaller, oval to elliptical avicularium, apparently without crossbar, was observed, also placed over the rows of areolar pores, but generally on the opposite side of the zooid with respect to the oral avicularium, and more proximally. Ovicell hyperstomial, globular, slightly flattened centrally, surrounded by a row of marginal pores with radial ridges in between; ectooecium surface with radial ribs and two large drop-shaped fenestrae $(0.04 \mathrm{~mm}$ long $\times 0.03 \mathrm{~mm}$ wide $)$.

Remarks.-Although the specimens studied here share some features with the type species of Hippomenella (see Berning, 2013) (e.g., the wide umbonuloid area and the presence of dimorphic adventitious avicularia), we assigned them to Hippopleurifera based on the characters of the ectooecium, which is bifenestrate, and the presence of 10 or more oral spines (Tilbrook, 2006; Ramalho et al., 2015). Twelve species of Hippopleurifera are known from the American continent, ten are fossil and two are Recent. Cheetham (1962b) introduced H. mcbeanensis, and Canu and Bassler (1920) described $H$. incondita, $H$. radicata, and $H$. rotula, all species from the Eocene of the southeastern USA; the latter authors also described $H$. costulata, $H$. crassicollis, $H$. ampla, and $H$. capitimortis from the Oligocene-Miocene of Alabama, USA; Ramalho et al. (2015) introduced $H$. confusa and $H$. barbosae from the Miocene of Brazil; H. mucronata (Smitt, 1873) and H. belizae Winston, 1984, are known from the Recent fauna of the Gulf of Mexico and the Caribbean.

Among the Oligocene-Miocene to Recent species, Hippopleurifera sp. indet. 1 resembles $H$. costulata in having a bifenestrate ooecium with radial ribs, and in the shape, size, and orientation of the oral avicularium; however, the latter species differs in having a single row of areolar pores, 4-6 oral spines, and in the absence of dimorphic avicularia. The bifenestrate ooecium and arrangement of the areolar pores also resemble $H$. capitimortis; however, in this species the ectooecium lacks the ribs, the fenestrae bear a proximal tongue, and the avicularia are absent or smaller in size and placed far from the orifice. In the Siamaná Formation, Hippopleurifera sp. indet. 1 was found encrusting the hydrocoral Millepora sp. and Caryophylliidae, as well as coralline algae covering the coral Porites sp., co-occurring with Gymnophorella hadra and Antropora guajirensis Flórez, Di Martino, and Ramalho, 2021.

\section{Hippopleurifera sp. indet. 2} Figure 10; Table 10

Occurrence.-Early Miocene, Siamaná Formation, Arroyo Ekieps, Colombia.

Description.-Colony encrusting, multiserial, unilaminar. Autozooids distinct by shallow interzooidal grooves, subhexagonal, rounded distally, slightly longer than wide (mean L/W 1.27). Frontal shield almost flat to slightly depressed, granular, central area imperforate, 3-4 rows of areolar pores. Orifice longer than wide, arched anter separated from the smaller and narrower poster (proximal border straight to slightly concave) by two blunt, rounded condyles; nine distolateral oral spine bases. One or two small, adventitious avicularia with raised, acutely triangular rostrum, oriented proximally to proximolaterally; when paired, avicularia placed symmetrically close to the lateral zooidal margins, almost at zooidal mid-length; occasionally a similar, slightly larger adventitious avicularium located laterally at the same level of the orifice, oriented lateroproximally; crossbar complete. Ovicells not observed.

Remarks.-The absence of ovicells in our specimens increases the uncertainty of its classification. However, we place this species in the genus Hippopleurifera based on the relatively reduced imperforate frontal area, the high number of oral spines, and the absence of dimorphic avicularia (Tilbrook, 2006; Ramalho et al., 2015). Among the eight species known from the American continent (see Remarks of Hippopleurifera sp. indet. 1), Hippopleurifera sp. indet. 2 resembles the Recent Caribbean species Hippopleurifera belizae Winston, 1984 , in the shape and location of the avicularia, as well as in its general aspect, but differs in the number of oral spines (9 instead of 6-8), and the morphology of the orifice, which is hoof-shaped instead of D-shaped. In the Siamaná Formation, 

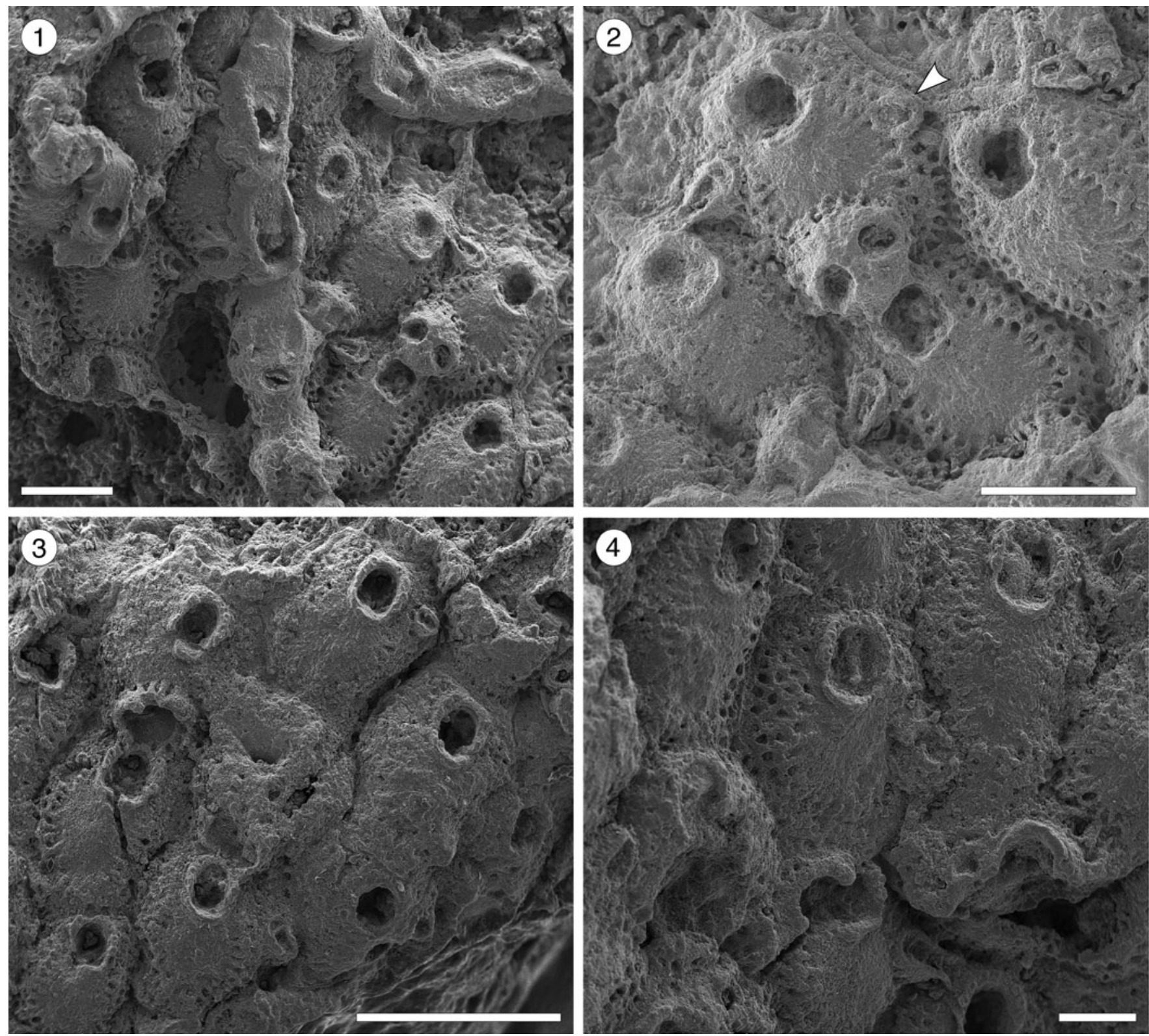

Figure 9. Hippopleurifera sp. indet. 1 from the Siamaná Formation, Arroyo Uitpa. (MUN-STRI-47690) (1) general view of the colony; (2) detail of the fertile zooid, showing the ridged and bifenestrate ectooecium and the elliptical avicularium (arrowed); (MUN-STRI-47689) (3) group of autozooids; (4) detail of the orifice and suboral peristome, oral spines, and marginal pores. Scale bars are $(\mathbf{1}, \mathbf{2}) 0.5 \mathrm{~mm} ;(\mathbf{3}) 1 \mathrm{~mm} ; \mathbf{( 4 )} 0.25 \mathrm{~mm}$.

Hippopleurifera sp. indet. 2 was found encrusting the coral Acropora panamensis and Acropora sp., co-occurring with Hippomenella sp. indet., Figularia bragai, Cribrilaria multicostata Flórez, Di Martino, and Ramalho, 2021,

Table 9. Measurements (in mm) of Hippopleurifera sp. indet. $1 . \mathrm{X}=$ mean; $\mathrm{R}=$ observed range; $\mathrm{SD}=$ standard deviation; $\mathrm{N}=$ number of measurements.

\begin{tabular}{lcccr}
\hline Character & X & R & SD & N \\
\hline Autozooid length & 0.80 & $0.77-0.82$ & 0.02 & 7 \\
Autozooid width & 0.65 & $0.63-0.68$ & 0.02 & 7 \\
Orifice length & 0.20 & $0.19-0.21$ & 0.01 & 10 \\
Orifice width & 0.16 & $0.15-0.18$ & 0.01 & 5 \\
Ooecium length & 0.32 & $0.28-0.35$ & 0.05 & 2 \\
Ooecium width & 0.41 & $0.39-0.42$ & 0.02 & 2 \\
Avicularium length & 0.22 & $0.13-0.28$ & 0.07 & 4 \\
\hline
\end{tabular}

Cribrilaria nixor Flórez, Di Martino, and Ramalho, 2021, Gemelliporidra aff. G. magniporosa, Poricella paulae n. sp., and other indeterminate cribrilinids.

Superfamily Schizoporelloidea Jullien, 1883

Family Schizoporellidae Jullien, 1883

Genus Gemelliporidra Canu and Bassler, 1927

Type species.-Gemelliporidra typica Canu and Bassler, 1927, from north of Cuba, Caribbean Sea, Recent; by original designation.

Gemelliporidra aff. G. magniporosa (Canu and Bassler, 1923) Figure 11.1-11.3; Table 11 

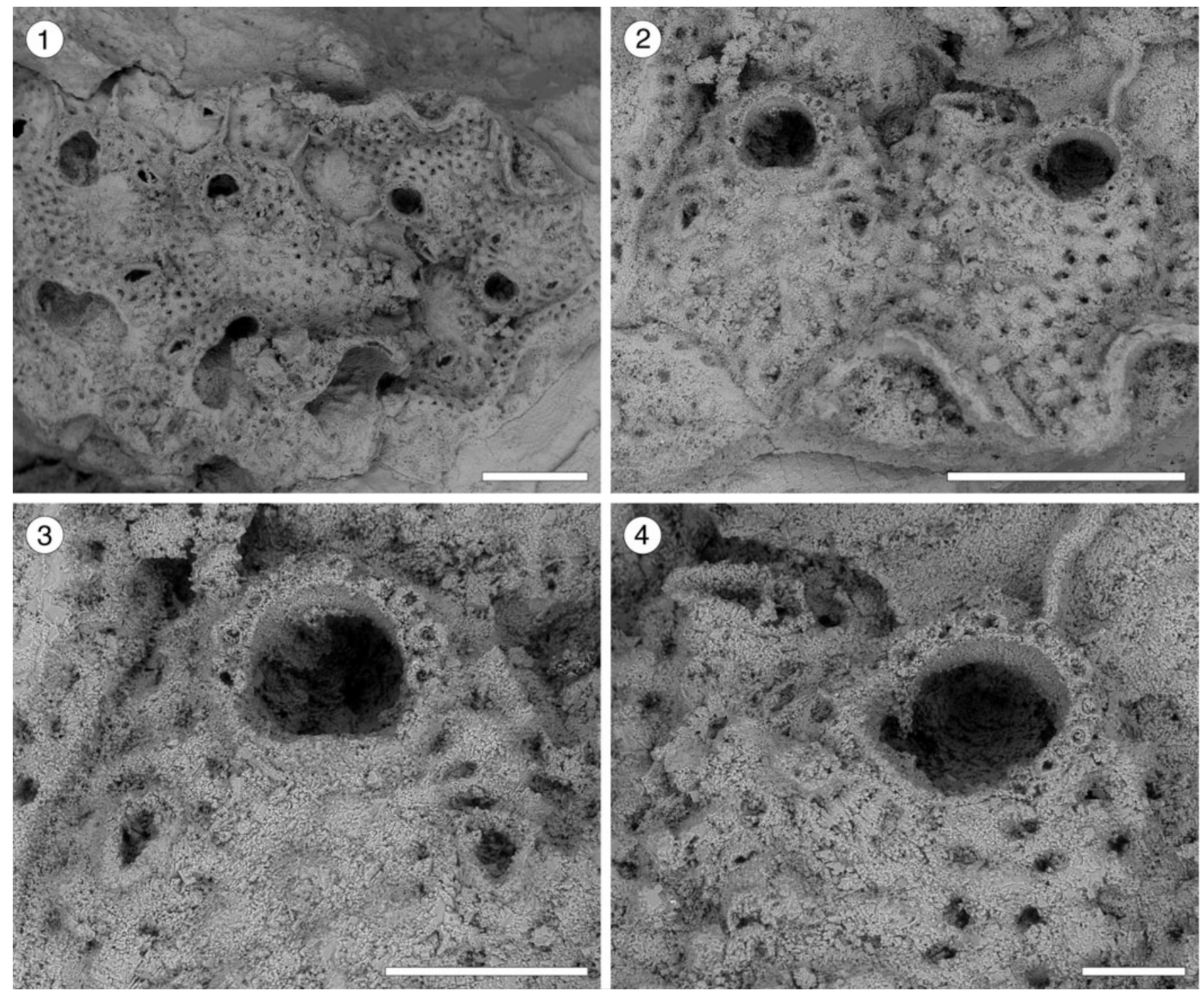

Figure 10. Hippopleurifera sp. indet. 2 (MUN-STRI-47691) from the Siamaná Formation, Arroyo Ekieps. (1) General view of the colony; (2) detail of two zooids showing the arrangement of the areolar pores, frontal avicularia, and lateral avicularium; (3) detail of the orifice, oral spine bases and paired frontal avicularia; (4) detail of the orifice, showing a condyle and oral spine bases, and a lateral avicularium. Scale bars are (1, 2) $0.5 \mathrm{~mm} ;(\mathbf{3}) 0.2 \mathrm{~mm} ;(\mathbf{4}) 0.1 \mathrm{~mm}$.

aff. 1923 Schizoporella magniporosa Canu and Bassler, p. 95, pl. 45 , figs. $1,2$.

aff. 1986 Gemelliporidra magniporosa; Winston, p. 19, fig. 41.

Syntype.-USNM 68535, from Mount Hope (Canal Zone), Panama. Pleistocene.

Occurrence.-Early Miocene, Siamaná Formation, Arroyo Ekieps, Colombia.

Table 10. Measurements (in mm) of Hippopleurifera sp. indet. 2. $\mathrm{X}=$ mean; $\mathrm{R}=$ observed range; $\mathrm{SD}=$ standard deviation; $\mathrm{N}=$ number of measurements.

\begin{tabular}{lcccr}
\hline Character & X & R & SD & N \\
\hline Autozooid length & 0.69 & $0.59-0.74$ & 0.06 & 5 \\
Autozooid width & 0.54 & $0.41-0.69$ & 0.10 & 7 \\
Orifice length & 0.17 & $0.15-0.18$ & 0.02 & 2 \\
Orifice width & 0.16 & $0.15-0.16$ & 0.01 & 2 \\
Avicularium length & 0.15 & $0.1-0.2$ & 0.04 & 8 \\
Avicularium width & 0.08 & $0.06-0.12$ & 0.02 & 7 \\
\hline
\end{tabular}

Description.-Colony encrusting, multiserial, unilaminar. Autozooids distinctly separated by a narrow groove or a thin thread, subrectangular to irregularly pentagonal, almost as long as wide (mean L/W 1.07). Frontal shield flat to slightly depressed, granular, evenly perforated by regularly spaced, circular pseudopores (diameter $0.02-0.04 \mathrm{~mm}$ ), except for a reduced imperforate area below the orifice. Orifice terminal, anter semielliptical, sinus rounded V-shaped, condyles rounded triangular. Small, triangular structures, seemingly oriented proximolaterally, placed at the distal zooidal margins, interpreted as putative adventitious avicularia. Ovicell hyperstomial, globular, occupying most of the frontal surface of the next distal zooid, up to the proximal margin of the orifice; apparently perforated by closely spaced pseudopores, smaller than those of the frontal shield.

Remarks.-Eight of the nine species of Gemelliporidra known to date are extant and recorded off the American continent: 

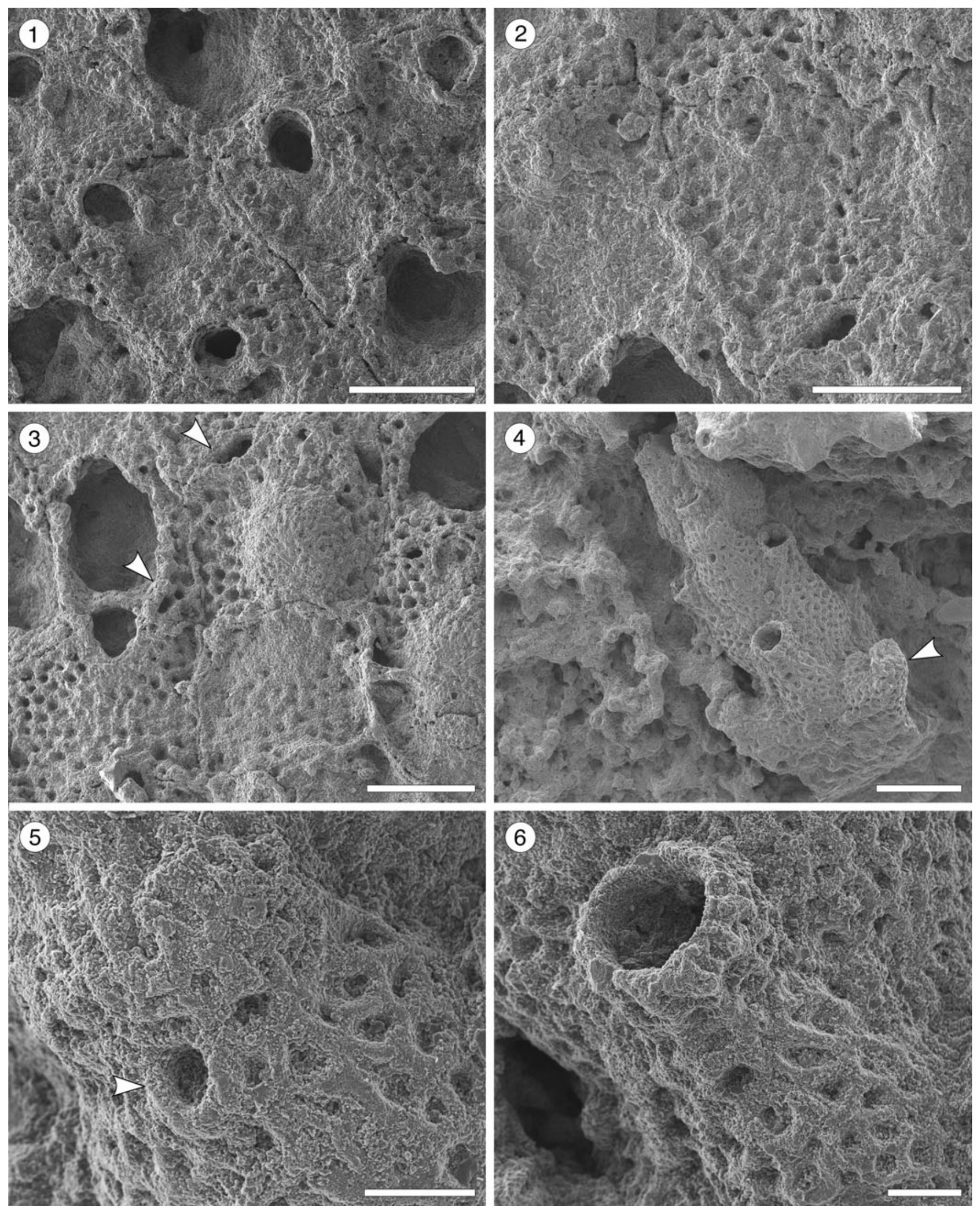

Figure 11. Gemelliporidra aff. G. magniporosa Canu and Bassler, 1923 (MUN-STRI-47701). (1) Detail the of zooidal shape; (2) detail of the orifice and pattern of pseudopores on the frontal shield; (3) detail of the orifice showing the V-shaped sinus, ovicell, and putative avicularia (arrowed). Margaretta cf. M. buski Harmer, 1957 (MUN-STRI-47705). (4) Branch fragment showing the upturned peristome of the fertile zooids (arrowed); (5) detail of the circular ascopore (arrowed); (6) detail of the peristome and secondary orifice. All illustrated specimens are from the Siamaná Formation, Arroyo Ekieps. Scale bars are $(\mathbf{1 - 4}) 0.5 \mathrm{~mm} ;(\mathbf{5 ,} \mathbf{6}) 0.1 \mathrm{~mm}$. 
Table 11. Measurements (in mm) of Gemelliporidra aff. G. magniporosa. X= mean; $\mathrm{R}=$ observed range; $\mathrm{SD}=$ standard deviation; $\mathrm{N}=$ number of measurements.

\begin{tabular}{lllll}
\hline Character & $\mathrm{X}$ & \multicolumn{1}{c}{$\mathrm{R}$} & $\mathrm{SD}$ & $\mathrm{N}$ \\
\hline Autozooid length & 0.75 & $0.65-0.87$ & 0.08 & 6 \\
Autozooid width & 0.70 & $0.56-0.88$ & 0.14 & 7 \\
Orifice length & 0.22 & $0.2-0.23$ & 0.02 & 3 \\
Orifice width & 0.18 & $0.16-0.19$ & 0.01 & 7 \\
Ooecium length & - & 0.52 & - & 1 \\
Ooecium width & - & 0.54 & - & 1 \\
\hline
\end{tabular}

G. colombiensis Osburn, 1952, and G. lata Osburn, 1952, from the Pacific coast of Colombia and California, respectively; G. aculeata Canu and Bassler, 1928, and G. pertusa (Smitt, 1873) from the Gulf of Mexico; G. multilamellosa Canu and Bassler, 1923, G. typica Canu and Bassler, 1927, and G. belikina Winston, 1984, from the Caribbean Sea; and $G$. magniporosa Canu and Bassler, 1923, from both the Gulf of Mexico and the Caribbean Sea. The size, shape, and position of the putative adventitious avicularia distinguish Gemelliporidra aff. G. magniporosa from all these congeners: G. typica, $G$. multilamellosa, and $G$. aculeata have larger, straight or curved avicularia; G. belikina and G. colombiensis have small, rounded to drop-shaped avicularia placed proximolateral to the orifice; avicularia are proximolateral to the orifice in G. lata: avicularia are oval and placed on the peristome in G. pertusa.

We assigned our specimens to $G$. aff. G. magniporosa based on the morphology of the autozooids, orifice, and ovicells, as well as the calcification of the frontal shield and the pattern of perforation. However, G. aff. G. magniporosa differs from the nominal species in having larger autozooids $(\mathrm{Lz} 0.75 \mathrm{~mm}, \mathrm{Wz}$ $0.70 \mathrm{~mm}$ vs. $\mathrm{Lz} 0.65 \mathrm{~mm}$, Wz $0.50-0.55 \mathrm{~mm}$ ) and orifices (Lo $0.22 \mathrm{~mm}$, Wo 0.18 vs. Lo $0.17 \mathrm{~mm}$, Wo 0.12), while the mean length/width ratios of both autozooids (1.07 vs. 1.18) and orifices (1.21 vs. 1.50) are lower. In addition, our specimens lack the paired, small, triangular avicularia placed at the sides of the orifice and oriented distomedially, as commonly found in G. magniporosa. In the Siamaná Formation, Gemelliporidra aff. G. magniporosa was found encrusting the corals Porites baracoaensis, Alveopora tampae, and Acropora sp., sharing the substrate with Calpensia caribensis Flórez, Di Martino, and Ramalho, 2021, Figularia bragai Flórez, Di Martino, and Ramalho, 2021, Hippomenella sp. indet., Hippopleurifera sp. indet. 2, and indeterminate cribrilinids.

\section{Family Margarettidae Harmer, 1957 Genus Margaretta Gray, 1843}

Type species.-Cellaria cereoides Ellis and Solander, 1786, from Algeria, Mediterranean Sea, Recent; by original designation.

Margaretta cf. M. buski Harmer, 1957

Figure 11.4-11.6; Table 12

cf. 1928 Tubucellaria cereoides; Canu and Bassler, p. 113, pl. 15, fig. 6.

cf. 1957 Margaretta buski Harmer, p. 834, pl. 55, fig. 29, text fig. 91.

cf. 2019 Margaretta cf. buski; Ramalho et al., p. 112, fig. 3.
Table 12. Measurements (in mm) of Margaretta $\mathrm{cf}$. M. buski. $\mathrm{X}=$ mean; $\mathrm{R}=$ observed range; $\mathrm{SD}=$ standard deviation; $\mathrm{N}=$ number of measurements.

\begin{tabular}{lcccr}
\hline Character & X & \multicolumn{1}{c}{ R } & SD & N \\
\hline Autozooid length & 0.91 & $0.82-1.06$ & 0.10 & 4 \\
Autozooid width & 0.39 & $0.35-0.42$ & 0.03 & 5 \\
Orifice diameter & 0.17 & $0.16-0.18$ & 0.01 & 5 \\
Peristome width & 0.19 & $0.11-0.26$ & 0.11 & 2 \\
Ascopore diameter & 0.03 & $0.03-0.04$ & 0.01 & 3 \\
Pseudopore diameter & 0.02 & 0.02 & 0 & 10 \\
\hline
\end{tabular}

Holotype.-NHMUK 87.12.9.439, from St. Paul's Rocks, shallow water, equatorial Atlantic Ocean, Brazil. Recent.

Occurrence.-Early Miocene, Siamaná Formation, Arroyo Ekieps, Colombia.

Description.-Colony erect, articulated. Autozooids flaskshaped, more than twice as long as wide (mean L/W 2.35), arranged in alternating whorls of three. Frontal shield evenly perforated by large, circular pseudopores, arranged in rows between ridges; circular ascopore placed medially at the base of the peristome. Peristome tubular, relatively short, ridged, and pseudoporous as the frontal shield. Fertile zooids with peristomes swollen proximally, upturned, and tapering distally. Secondary orifice circular, primary orifice hidden by the peristome. Basis rami bipartite.

Remarks.-Six fossil species of Margaretta were recorded from the American continent in addition to M. buski. Canu and Bassler (1920) introduced (as Tubucellaria) the species $M$. fallax, $M$. nodifera, and $M$. parviporosa from the Eocene of Alabama, Florida, and North Carolina, respectively, and M. vicksburgica from the Oligocene of Alabama. Margaretta cf. M. buski differs from all these species in having smaller zooids ( $<1 \mathrm{~mm}$ long); in addition, $M$. nodifera has zooids with tuberosities. The Eocene species $M$. congesta (Cheetham, 1963) and the Miocene species M. pentaceratops Di Martino, Taylor, and Portell, 2017, both from Florida, differ from $M$. cf. $M$. buski in having eight rows of smaller and densely packed zooids and peristome with five spiniform processes, respectively. Margaretta cf. M. buski resembles the Miocene to Recent M. cereoides (Ellis and Solander, 1786), known from the Mediterranean and East Atlantic, in general appearance, including the shape and arrangement of autozooids; however, it differs in having bipartite basis rami instead of undivided, and three zooids per whorl instead of four or five (Harmer, 1957). The early Miocene Siamaná specimen differs from the holotype of the nominal species (see Di Martino et al., 2017, fig. 49) in having curved but not inturned fertile peristomes, which also has been observed in specimens from the Miocene Pirabas Formation of Brazil (Ramalho et al., 2019, fig. 3). However, the limited amount of material available prevents determination of whether this is a genuine morphological difference or a diagenetic effect. The small fragments of Margaretta cf. M. buski were found in sediment cemented to the corals Goniopora hilli and Acropora panamensis, co-occurring with Nellia cf. N. tenella (Lamarck, 1816), Ditaxiporina colombiana n. sp., Mecynoecia sp., Catenicella sp., Reteporellina sp., and Glabrilaria sp. 

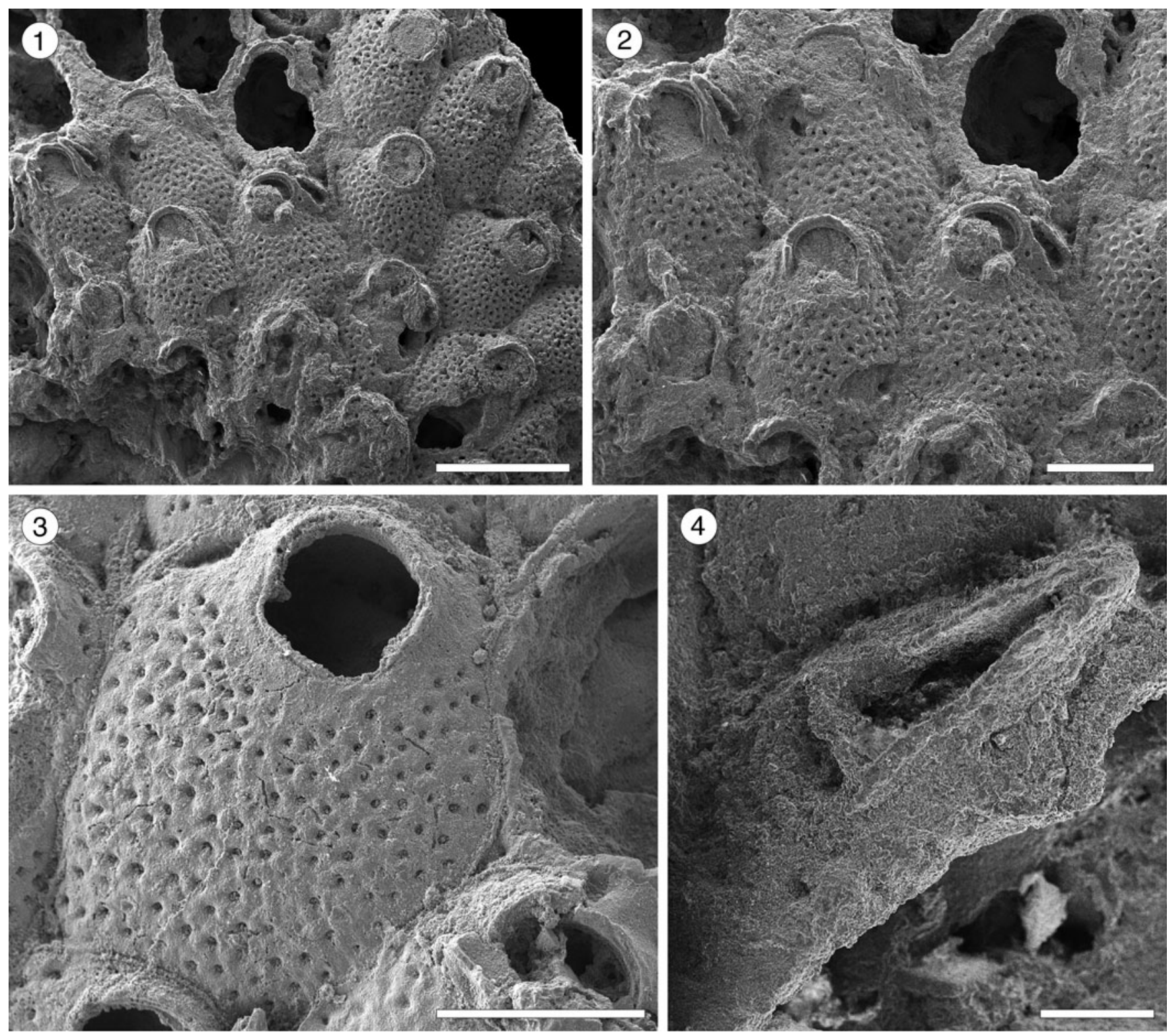

Figure 12. Hippopodina sp. indet. (MUN-STRI-47707). (1) General view of a colony fragment; (2) detail of the zooids bearing latero-oral avicularia; (MUN-STRI-47708) (3) detail of a zooid, with orifice showing a condyle; (4) detail of an avicularium with complete crossbar. All illustrated specimens are from the Siamaná Formation, Arroyo Ekieps. Scale bars are (1) $1 \mathrm{~mm} ;(\mathbf{2}, \mathbf{3}) 0.5 \mathrm{~mm} ; \mathbf{( 4 )} 0.1 \mathrm{~mm}$.

Family Hippopodinidae Levinsen, 1909

Genus Hippopodina Levinsen, 1909

Type species.—Lepralia feegeensis Busk, 1884, from Bisayas Sea, Philippines, Recent; by original designation.

\section{Hippopodina sp. indet.}

Figure 12; Table 13

Occurrence.-Early Miocene, Siamaná Formation, Arroyo Ekieps, Colombia.

Description.-Colony encrusting, multiserial, unilaminar. Autozooids separated by deep furrows and a narrow thread, rounded polygonal, longer than wide (mean L/W 1.38). Frontal shield convex, finely granular, evenly perforated by numerous
( 130), circular pseudopores, $\sim 0.02 \mathrm{~mm}$ in diameter. Larger, fusiform pores at the distal corners of the zooids sometimes visible. Orifice terminal, hoof-shaped, two robust condyles separating a semicircular anter from a shallow, broad sinus with proximal border flat or slightly concave. Adventitious avicularium single, sometimes absent, lateral to the orifice, originating at the same level as the orifice proximal margin and extending for the total length of the orifice; rostrum raised, narrow and acutely triangular, oriented distolaterally or medially; crossbar complete. Ovicells not observed.

Remarks. - In the fossil record of North America two species of Hippopodina are known from the Eocene of Georgia and Florida (USA): $H$. stephensi Cheetham, 1962b, and $H$. vibraculifera Canu and Bassler, 1917, respectively. The 
Table 13. Measurements (in $\mathrm{mm}$ ) of Hippodina $\mathrm{sp}$. indet. $\mathrm{X}=$ mean; $\mathrm{R}=$ observed range; $\mathrm{SD}=$ standard deviation; $\mathrm{N}=$ number of measurements.

\begin{tabular}{lcccr}
\hline Character & X & R & SD & N \\
\hline Autozooid length & 1.12 & $0.97-1.24$ & 0.09 & 14 \\
Autozooid width & 0.82 & $0.71-1.00$ & 0.08 & 11 \\
Orifice length & 0.32 & $0.29-0.35$ & 0.02 & 8 \\
Orifice width & 0.31 & $0.29-0.34$ & 0.02 & 9 \\
Avicularium length & 0.40 & $0.36-0.45$ & 0.05 & 3 \\
Avicularium width & 0.13 & $0.12-0.15$ & 0.02 & 3 \\
\hline
\end{tabular}

former species differs from Hippopodina sp. indet. in often having paired adventitious avicularia, placed and directed proximolaterally to the orifice, while the latter species has avicularia placed distally and oriented proximally.

In addition, five Recent species are known from off North America: H. pulcherrima (Canu and Bassler, 1928) from the Western Atlantic; H. bernardi Lagaaij, 1963, from the Gulf of Mexico; H. irregularis Osburn, 1940, from the Caribbean Sea; H. tahitiensis Leca and d'Hondt, 1993, allegedly from the Caribbean Sea, India, and Africa; and H. californica Osburn, 1952, from the Pacific coast of the USA. However, Hippopodina californica and $H$. irregularis lack avicularia; $H$. bernardi has a centrally imperforate frontal shield; $H$. tahitiensis bears single or paired, small, drop-shaped avicularia placed distolaterally and oriented distally; and $H$. pulcherrima, the most common in the Caribbean region (Tilbrook, 1999), has a narrower sinus and single or paired avicularia, located beside the orifice and oriented proximomedially.

Three species of Hippopodina are known from the earlymiddle Miocene of other geographic regions: H. lappi David, 1965, from France lacks avicularia; H. emerensis Abbas and El-Senoussi, 1979, from Egypt has adventitious avicularia on either side of the orifice; and $H$. indicata Di Martino and Taylor, 2015, found in coral reefs from East Kalimantan, has similar adventitious avicularia but originating more proximally and with the rostrum pointing to the orifice condyles. Our specimens resemble the Recent species H. iririkiensis Tilbrook, 1999, recorded in the Indo-West Pacific, Australia, and the Mediterranean Sea in the shape, location, and direction of the single avicularium; however, in $H$. iririkiensis, avicularia are often paired, Hippopodina sp. indet. has larger zooids $(1.12 \times 0.82 \mathrm{~mm}$ vs. $0.9 \times 0.62 \mathrm{~mm}$ ), and the proximal margin of the orifice is flatter. However, the limited amount of material available and the lack of ovicells in our specimens prevented us from confirming its conspecificity with previously described species and from describing a new species. In the Siamaná Formation, Hippopodina sp. indet. was found encrusting the coral species Porites anguillensis and Millepora sp., co-occurring with Poricella paulae n. sp.

Family Teuchoporidae Neviani, 1895a

Genus Cycloavicularia new genus

Type species.-Cycloavicularia parva n. sp., from Arroyo Ekieps, Colombia, early Miocene, Siamaná Formation; by monotypy.

Diagnosis. - As for the type species.

Etymology.-From the Latinized form of the Greek kyklos, meaning circle, plus the morphologic term avicularia, alluding to the circular, adventitious avicularia placed on the zooidal 'shoulders.'

Remarks.-We place this new genus in the family Teuchoporidae based on the following characters: frontal shield evenly perforated, peristome moderately high, presence of small adventitious avicularia, and a conspicuous and perforated ooecium that is proximally encroached by the peristome (Harmer, 1957; Poluzzi, 1977; Gordon, 1984). This family includes three genera: Teuchopora Neviani, 1895b (type), "Coleopora" Canu and Bassler, 1927, and Lagenicella Cheetham and Sandberg, 1964. Cycloavicularia n. gen. differs from Teuchopora and "Coleopora" in having adventitious avicularia while lacking the proximal peristomial denticle. It differs also from Lagenicella in having polygonal rather than vase-shaped zooids, and in the lack of imperforate, hood-like projections rimming the peristomial ovicells. Cycloavicularia n. gen. also shows some similarities with members of the family Exechonellidae Harmer, 1957, which, however, usually lack or have inconspicuous ovicells (Gordon, 1984).

The type species of this new genus closely resembles the Recent Brazilian species Marcusadorea pinheroi Almeida et al., 2017, in its overall appearance, size of the zooids and ovicells, and density and distribution of pseudopores, but differs in having avicularia. Its allocation in Marcusadorea, however, would not be justified because Marcusadorea jamaicensis Vieira, Migotto, and Winston, 2010, the type species of the genus and family Marcusadoreidae Winston, Vieira, and Woollacott, 2014, has an irregularly perforated frontal shield, marginal areolar pores are distinct from the pseudopores, and peristomial avicularia are sometimes present (Vieira et al., 2010), while Cycloavicularia parva n. gen. n. sp. has an evenly perforated frontal shield and distinctive, small, adventitious avicularia in the distolateral corners of the zooids.

\section{Cycloavicularia parva new species Figure 13; Table 14}

Holotype.-MUN-STRI-47709, from the lower Miocene Siamaná Formation, Arroyo Ekieps, La Guajira, Colombia.

Diagnosis.-Colony encrusting. Orifice surrounded by a well-developed, imperforate peristome, taller distolaterally, forming an U-shaped peristomial sinus proximally. Frontal shield granular, evenly pseudoporous except for the peristome. Two small, circular, adventitious avicularia placed at distolateral corners of autozooids. Ovicell globular; ooecium granular and pseudoporous as the frontal shield, encroached proximally by the peristome.

Description.-Colony encrusting, multiserial, uni- to multilaminar. Autozooids large, distinct by narrow grooves, recumbent to semi-erect, rhomboidal to irregularly polygonal, slightly longer than wide (mean L/W 1.15). Frontal shield slightly convex, granular, evenly perforated, except for the peristome, by 20-100 (depending on the length of the zooid) circular pseudopores $\sim 0.03 \mathrm{~mm}$ in diameter; occasionally $2-3$ rows of marginal pores distally. Orifice terminal to subterminal; primary orifice hidden by a distolaterally 

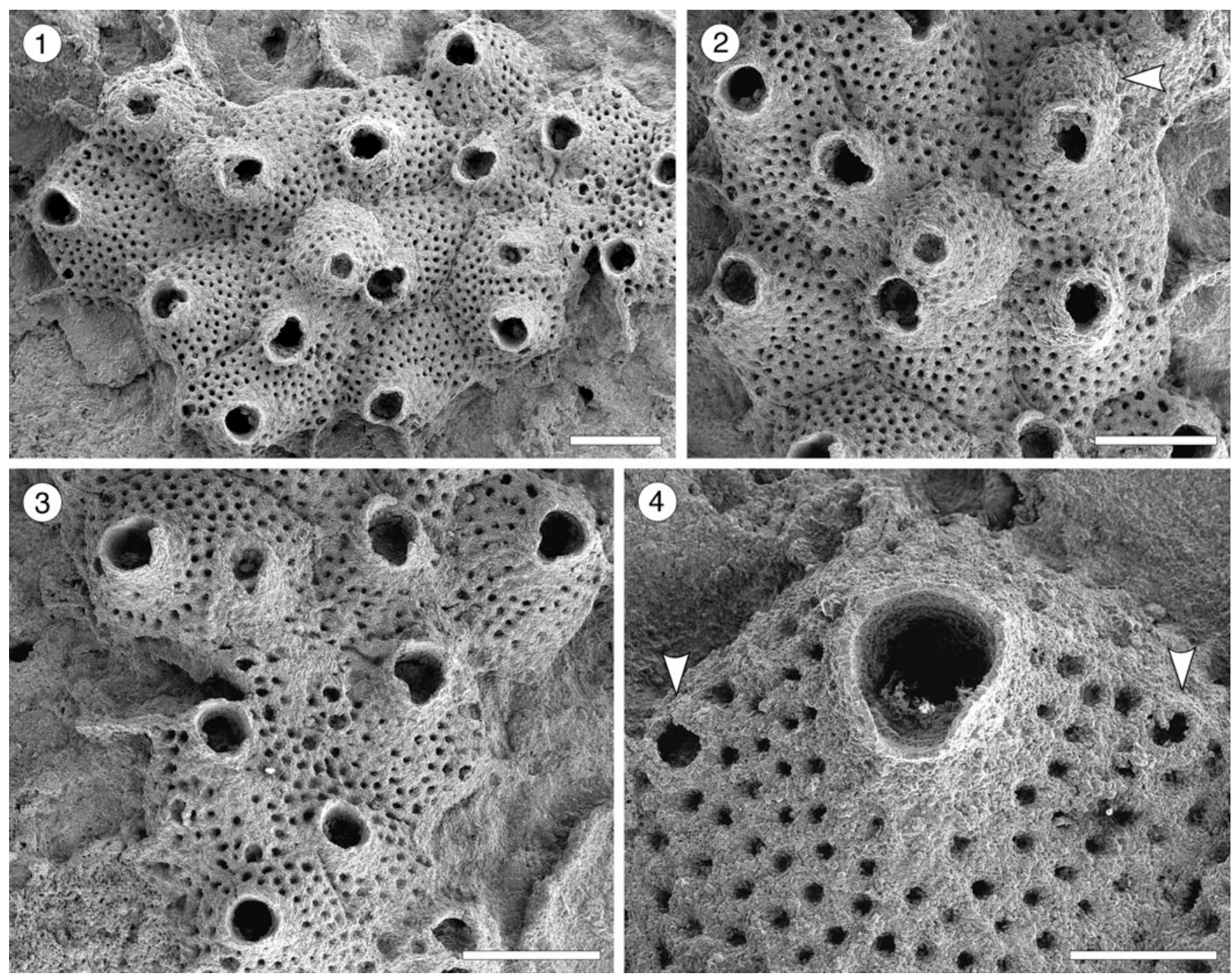

Figure 13. Cycloavicularia parva n. gen. n. sp. (Holotype MUN-STRI-47709) from the Siamaná Formation, Arroyo Ekieps. (1) General view of the colony; (2) detail of a group of recumbent zooids and a fertile zooid (arrowed); (3) detail of the peristome and sinus of the secondary orifice; (4) detail of the rounded avicularia (arrowed). Scale bars are (1-3) $0.5 \mathrm{~mm} ;(\mathbf{4}) 0.2 \mathrm{~mm}$.

well-developed peristome forming a secondary orifice with U-shaped sinus; secondary orifice slightly larger in ovicellate zooids. Adventitious avicularia small, circular, placed on the distolateral corners of the autozooids; crossbar or pivotal condyles not preserved. Ovicell produced by the distal zooid; hyperstomial, globular, opening into the peristome (acleithral);

Table 14. Measurements (in mm) of Cycloavicularia parva $n$. gen. $n$. $\mathrm{sp} . \mathrm{X}=$ mean; $\mathrm{R}=$ observed range; $\mathrm{SD}=$ standard deviation; $\mathrm{N}=$ number of measurements.

\begin{tabular}{lcccr}
\hline Character & $\mathrm{X}$ & $\mathrm{R}$ & $\mathrm{SD}$ & $\mathrm{N}$ \\
\hline Autozooid length & 0.77 & $0.54-0.94$ & 0.12 & 8 \\
Autozooid width & 0.67 & $0.6-0.84$ & 0.09 & 8 \\
Primary orifice length & 0.18 & $0.17-0.19$ & 0.01 & 2 \\
Primary orifice width & 0.18 & $0.17-0.18$ & 0.01 & 2 \\
Secondary orifice length & 0.22 & $0.21-0.25$ & 0.01 & 12 \\
Secondary orifice width & 0.18 & $0.16-0.21$ & 0.01 & 11 \\
Avicularium diameter & 0.12 & $0.1-0.14$ & 0.01 & 10 \\
Avicularian opesia diameter & 0.06 & 0.06 & 0 & 7 \\
Ooecium length & - & 0.24 & - & 1 \\
Ooecium width & - & 0.4 & - & 1 \\
\hline
\end{tabular}

ooecium surface granular and pseudoporous as the frontal shield. Ancestrula unknown.

Etymology.-From the Latin parvus, meaning little, in reference to the reduced size of the adventitious avicularia.

Remarks.-Cycloavicularia parva n. gen. n. sp. resembles the Indo-Pacific Recent species Cosciniopsis lonchaea (Busk, 1884) in having a well-developed peristome, a tuberculate and pseudoporous frontal shield, and adventitious avicularia, but the latter species has one or two triangular avicularia close to the orifice, conspicuous condyles, lateral walls with uniporous septula, and ovicells that are closed by the operculum (cleithral) (Tilbrook, 2006, p. 236-237, pl. 52, figs. a-c). Species of the genus Saevitella Bobies, 1956, also have granular and pseudoporous frontal shields and ovicells, but lack avicularia and have cleithral ooecia (Berning, 2012, p. 43, figs. 13-18). In the Siamaná Formation, Cycloavicularia parva n. gen. n. sp. was found encrusting cavities of the coral Porites anguillensis. 

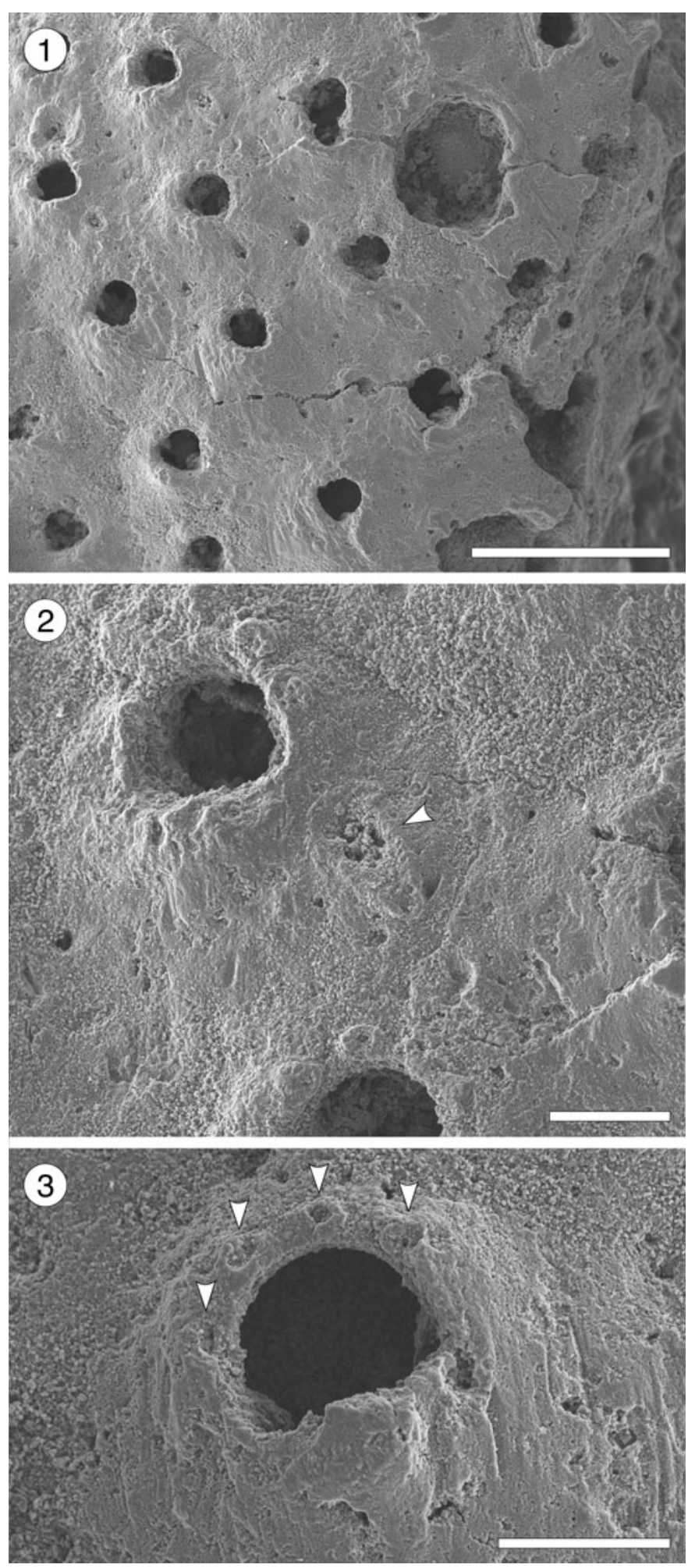

Figure 14. Pleuromucrum sp. indet. (MUN-STRI-47710) from the Siamaná Formation, Arroyo Uitpa. (1) General view of a colony fragment; (2) detail of a zooid bearing a triangular avicularium (arrowed); (3) detail of the orifice showing four oral spine bases (arrowed), condyles, and suboral umbo. Scale bars are (1) $0.5 \mathrm{~mm} ;(\mathbf{2}, \mathbf{3}) 0.1 \mathrm{~mm}$.

Superfamily Celleporoidea Johnston, 1838 Family Phidoloporidae Gabb and Horn, 1862 Genus Pleuromucrum Vigneaux, 1949
Table 15. Measurements (in $\mathrm{mm}$ ) of Pleuromucrum sp. indet. $\mathrm{X}=$ mean; $\mathrm{R}=$ observed range; $\mathrm{SD}=$ standard deviation; $\mathrm{N}=$ number of measurements.

\begin{tabular}{lllll}
\hline Character & $\mathrm{X}$ & $\mathrm{R}$ & $\mathrm{SD}$ & $\mathrm{N}$ \\
\hline Autozooid length & 0.44 & $0.43-0.45$ & 0.01 & 4 \\
Autozooid width & 0.37 & $0.31-0.42$ & 0.05 & 4 \\
Orifice length & 0.10 & $0.09-0.11$ & 0.01 & 9 \\
Orifice width & 0.11 & $0.10-0.12$ & 0.01 & 8 \\
Avicularium length & 0.12 & $0.11-0.13$ & 0.01 & 3 \\
Avicularium width & 0.08 & 0.08 & 0 & 2 \\
Ooecium length & - & 0.12 & - & 1 \\
Ooecium width & - & 0.15 & - & 1 \\
\hline
\end{tabular}

Type species.-Pleuromucrum saucatsense Vigneaux, 1949, from Saucats (Pont-Pourquey), France, Burdigalian; by original designation.

\section{Pleuromисrum sp. indet.}

Figure 14; Table 15

Occurrence.-Early Miocene, Siamaná Formation, Arroyo Uitpa, Colombia.

Description.-Colony encrusting, multiserial, unilaminar. Autozooids almost indistinct, boundaries apparently concealed by secondary calcification, subrhomboidal to oval, slightly longer than wide (mean L/W 1.19). Frontal shield smooth, generally slightly depressed, but raised suborally, imperforate except for 2-4 small marginal areolar pores. Orifice bell-shaped, almost as long as wide, bearing two robust, triangular condyles; four distolateral oral spine bases; proximal border with a poorly developed or poorly preserved umbo. Adventitious avicularium single, placed on one side of the frontal shield slightly below the orifice; rostrum rounded triangular, directed proximolaterally, seemingly with pivotal condyles. Ooecium broken, apparently small and circular in outline.

Remarks.-We place this specimen in Pleuromucrum based on the shape of the orifice, the imperforate frontal shield with few, sparse marginal pores, the presence of frontal triangular avicularia, oral spines and suboral umbo, and the proportionally small ooecium in respect to autozooid size (Di Martino and Taylor, 2017). The smooth appearance of the frontal shield (in Pleuromucrum it is usually nodular) is likely due to preservation, which also prevents species-level assignment. In the Siamaná Formation, Pleuromucrum sp. indet. was found encrusting coralline algae.

\section{Genus Reteporellina Harmer, 1933}

Type species.-Retepora denticulata Busk, 1884, from Honolulu, Hawaii, North Pacific, Recent; by original designation.

\section{Reteporellina sp. indet.}

Figure 15; Table 16

Occurrence.-Early Miocene, Siamaná Formation, Arroyo Ekieps, Colombia.

Description.-Colony erect, rigid. Branches cylindrical to slightly flattened, $0.32-0.50 \mathrm{~mm}$ wide. Autozooids distinct, 

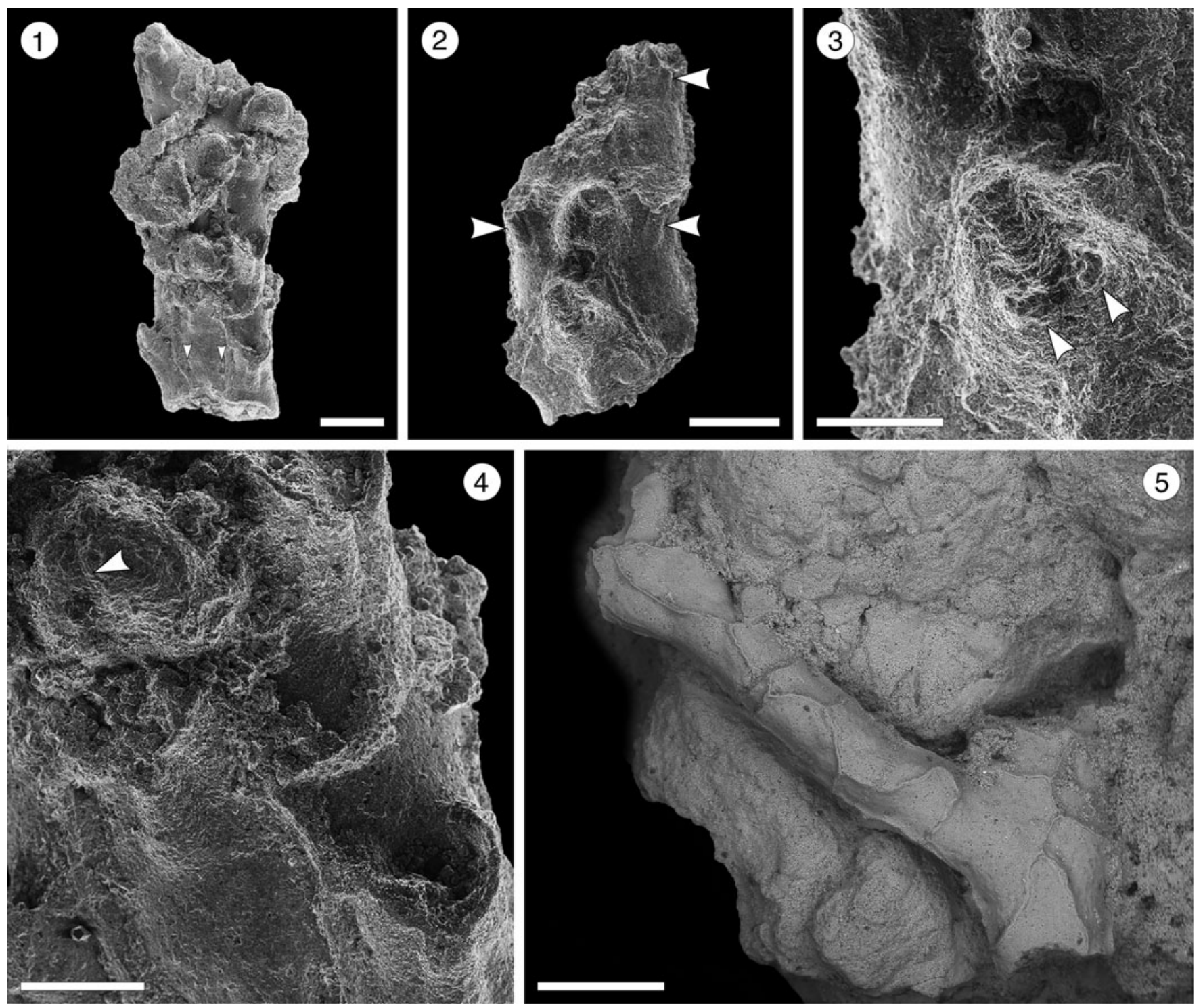

Figure 15. Reteporellina sp. indet. from the Siamaná Formation, Arroyo Ekieps: (MUN-STRI- 47712). (1) General view of the branch fragment showing three rows of zooids and the areolar pores (arrowed); (2) detail of the sinus in the peristome (arrowed); (3) detail of the bifid suboral avicularium (arrowed); (4) detail of the medial suture of the ovicell (arrowed); (5) detail of the vibices of the abfrontal surface. Scale bars are $(\mathbf{1 , 2}) 0.2 \mathrm{~mm} ;(\mathbf{3}, \mathbf{4}) 0.1 \mathrm{~mm} ;(\mathbf{5}) 0.5 \mathrm{~mm}$.

separated by raised ridges, subrhomboidal, arranged alternately in three longitudinal rows on the frontal side of the branch, more than twice as long as wide (mean L/W 2.10). Primary orifice hidden by a proximally well-developed peristome with a U-shaped sinus medially. Frontal shield slightly convex, perforated by a pair of marginal areolar pores placed proximally at about one-third of the total length of the zooid.

Table 16. Measurements (in $\mathrm{mm}$ ) of Reteporellina sp. indet. $\mathrm{X}=$ mean; $\mathrm{R}=$ observed range; $\mathrm{SD}=$ standard deviation; $\mathrm{N}=$ number of measurements.

\begin{tabular}{lllll}
\hline Character & $\mathrm{X}$ & \multicolumn{1}{c}{$\mathrm{R}$} & $\mathrm{SD}$ & $\mathrm{N}$ \\
\hline Autozooid length & 0.36 & $0.3-0.41$ & 0.06 & 3 \\
Autozooid width & 0.17 & $0.17-0.18$ & 0.01 & 3 \\
Orifice length & - & 0.08 & - & 1 \\
Orifice width & 0.10 & $0.09-0.1$ & 0.01 & 4 \\
Avicularium length & - & 0.13 & - & 1 \\
Ooecium width & 0.16 & $0.15-0.17$ & 0.01 & 4 \\
\hline
\end{tabular}

Adventitious avicularia large, placed on a suboral, raised cystid; rostrum bifid, oriented latero-frontally. Ovicell hyperstomial, globular, longer than wide, seemingly with a medial suture. Abfrontal surface smooth with irregular vibices; no avicularia or pores observed.

Remarks.-Seven Recent species of Reteporellina are known in America: R. marsupiata (Smitt, 1873) from the West Atlantic; $R$. prominens (Canu and Bassler, 1928) from the Gulf of Mexico; $R$. directa Winston and Woollacott, 2009, from Barbados; $R$. evelinae Marcus, 1955, from Brazil; $R$. moyanoi d'Hondt, 1981, from Uruguay and the Pacific coast; $R$. bilabiata Osburn, 1952, from the Gulf of California; and R. denticulata gracilis Osburn, 1952, from Ecuador and Costa Rica. Among them, $R$. directa and $R$. moyanoi differ from Reteporellina sp. indet. in having the frontal avicularia oriented proximally not latero-frontally. Reteporellina prominens and $R$. denticulata 

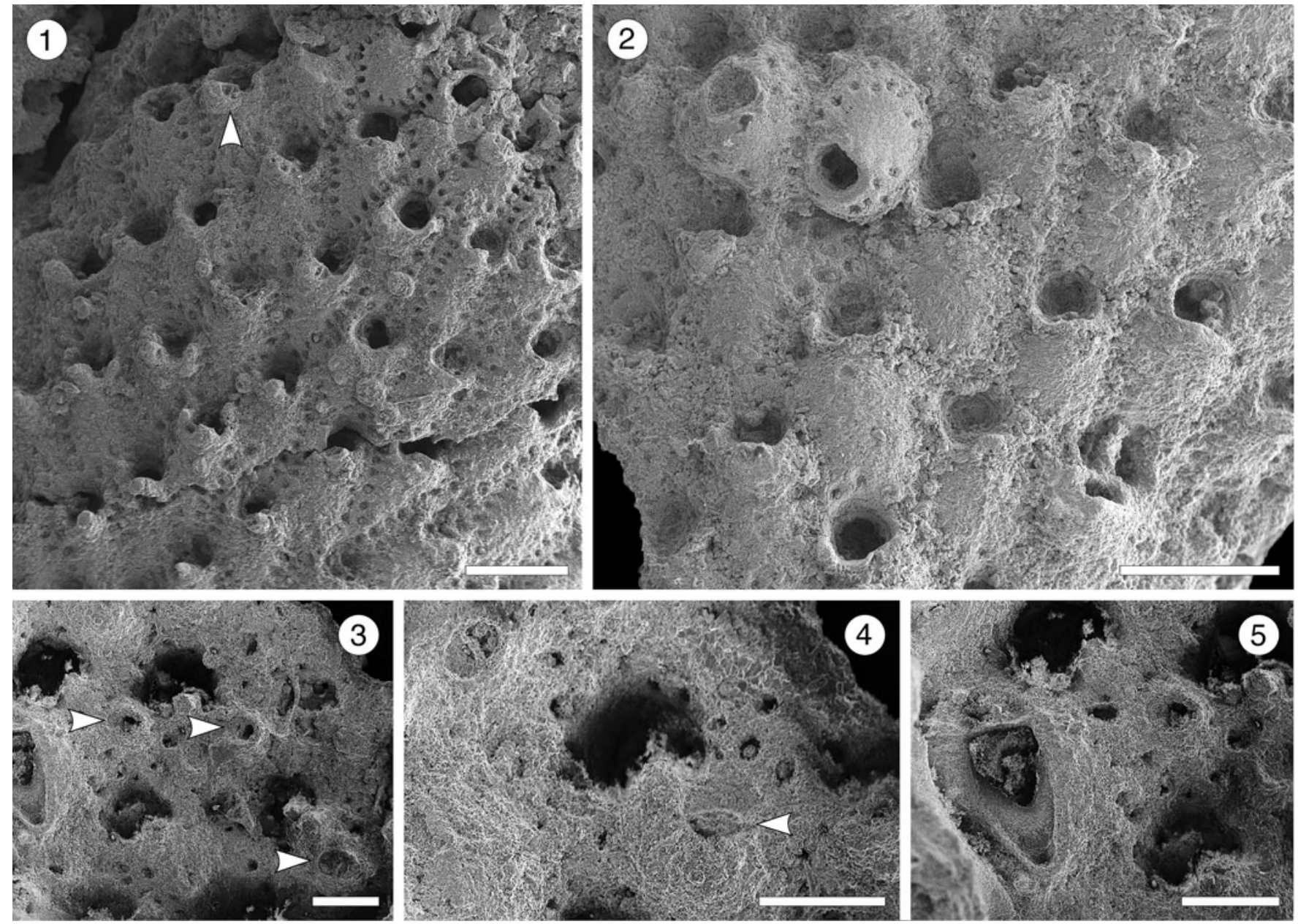

Figure 16. Rhynchozoon sp. indet. from the Siamaná Formation, Arroyo Ekieps: (MUN-STRI-47713). (1) General view of the colony fragment, and suboral avicularia (arrowed); (2) group of zooids, some of them showing the primary subcircular orifice; (3) detail of erect zooids and rounded avicularia (arrowed); (4) detail of the secondary orifice showing the suboral avicularium (arrowed); (5) detail of the triangular interzooidal avicularium. Scale bars are (1,2) $0.5 \mathrm{~mm} ;(\mathbf{3}-\mathbf{5}) 0.2 \mathrm{~mm}$.

gracilis have small frontal avicularia that are rounded and drop-shaped, respectively; $R$. bilabiata has frontal avicularia with a triangular rostrum, placed proximolateral to the orifice, and avicularia also on the abfrontal surface. Reteporellina sp. indet. closely resembles $R$. evelinae and $R$. marsupiata in the arrangement of zooids and in having frontal avicularia with bifid rostra. However, poor preservation of the specimen prevents any further comparison. In the Siamaná Formation, Reteporellina sp. indet. was found in sediment adhering to the corals Acropora panamensis and Caryophyllidae sp., co-occurring with Catenicella sp., Licornia sp., Margaretta cf. M. buski, and Ditaxiporina colombiana $\mathrm{n}$. sp.

\section{Genus Rhynchozoon Hincks, 1895}

Type species.—Lepralia bispinosa Johnston, 1847, from Berwick Bay, United Kingdom, North Sea, Recent; by original designation.

\section{Rhynchozoon sp. indet.}

Figure 16; Table 17

Description.-Colony encrusting, multiserial, uni- to multilaminar. Autozooids at the colony growing edge, distinct, oval to claviform, longer than wide (mean L/W 1.82), but indistinct, erect to semi-erect, and irregularly arranged in central, older areas. Frontal shield convex, smooth to slightly ribbed, imperforate except for 14-16 circular to drop-shaped marginal areolar pores $(0.03 \mathrm{~mm}$ in diameter) separated by ridges. Orifice subcircular. Suboral mucro bearing apically a small, rounded avicularium with complete crossbar, rostrum oriented laterally. Often, two additional, raised hooked processes flanking the medial mucro. Dimorphic interzooidal avicularia placed between the erect zooids: either large,

Table 17. Measurements (in $\mathrm{mm}$ ) of Rhynchozoon sp. indet. $\mathrm{X}=$ mean; $\mathrm{R}=$ observed range; $\mathrm{SD}=$ standard deviation; $\mathrm{N}=$ number of measurements.

\begin{tabular}{lcccc}
\hline Character & X & R & SD & N \\
\hline Autozooid length & 0.65 & $0.54-0.72$ & 0.07 & 5 \\
Autozooid width & 0.36 & $0.33-0.41$ & 0.03 & 6 \\
Orifice length & 0.14 & $0.13-0.14$ & 0.01 & 3 \\
Orifice width & 0.15 & $0.14-0.17$ & 0.02 & 3 \\
Rounded suboral avicularium length & 0.12 & $0.11-0.13$ & 0.01 & 3 \\
Rounded suboral avicularium width & 0.09 & $0.08-0.09$ & 0.01 & 3 \\
Triangular suboral avicularium length & - & 0.43 & - & 1 \\
Triangular suboral avicularium length & - & 0.28 & - & 1 \\
Frontal avicularium length & 0.14 & $0.13-0.15$ & 0.01 & 2 \\
Frontal avicularium length & 0.11 & 0.11 & 0 & 2 \\
\hline
\end{tabular}


triangular, placed proximolateral to the orifice and oriented proximally, or elliptical and oriented proximolaterally; both types with complete crossbar. Ovicells not observed.

Remarks.-Based on its general appearance, including the arrangement of zooids, the well-developed suboral processes, and the monomorphic suboral avicularia, we assign these specimens to Rhynchozoon. However, the poor preservation prevents the comparison with congeners and nomenclature remains open. In the Siamaná Formation, Rhynchozoon sp. indet. was found encrusting the hydrocoral Millepora alcicornis Linnaeus, 1758, and the scleractinian Colpophyllia willoughbiensis, co-occurring with Calpensia caribensis and Copidozoum sp. indet.

\section{Discussion}

The study area comprises patch reefs distributed in a shallow lagoon and in the discontinuous coral barrier enclosing the lagoon (Flórez, 2020). These coral communities thrived in tropical waters, at depths of 2-30 m, with low turbidity, low energy, and limited siliciclastic input (Flórez et al., 2019a, b; Flórez, 2020). Associated with them, we found 32 bryozoan species (Flórez et al., 2021; this paper).

New species account for $31 \%$ (10 species) of the whole assemblage. Three new species belong to the family Cribrilinidae, and one each to Antroporidae, Microporidae, Onychocellidae, Steginoporellidae, Catenicellidae, Arachnopusiidae and Teuchoporidae. The new genera, Atoichos Flórez et al., 2021, in Onychocellidae; Gymnophorella Flórez et al., 2021, in Steginoporellidae; and Cycloavicularia n. gen. in Teuchoporidae, also have been introduced to accommodate three new species.

Two species are identified as confer and another three as affinis to preexisting species. The remaining species $(53 \%)$ were left in open nomenclature, one identified at family level and 15 at genus level. This high percentage of undetermined species is due to the poor preservation caused by weathering, dissolution and recrystallization, and/or mechanical abrasion, which resulted in the loss or alteration of key skeletal features. It is well known that tropical Cenozoic carbonates, especially coral reefs, experience rapid cementation (Macintyre, 2011), and severe diagenetic alterations greatly affecting aragonitic organisms, even to the complete disappearance of the aragonitic component. Taylor and Di Martino (2014) found that $27 \%$ of tropical cheilostome species encrusting the underside of platy corals were aragonitic and $30 \%$ bimineralic. These results suggest that species richness may suffer a great loss in this tropical paleoenvironment, although it has also been observed that in some particular conditions the originally aragonitic skeletons of bryozoans can be preserved by calcitization (Di Martino et al., 2016). Furthermore, the preservation of bryozoan colonies may also be affected by the diagenetic processes affecting their aragonitic substrates, such as scleractinian corals (as in this case) or mollusks (Taylor and Di Martino, 2014).

The relative proportions of cyclostomes $(6 \%)$ and cheilostomes $(94 \%)$ follow the general pattern observed in the Caribbean region from the Miocene to the Pleistocene (Cheetham et al., 1999; Taylor, 2001), and in Recent coral-associated bryozoan faunas (Winston, 1986).
In the Siamaná Formation, $75 \%$ of species are encrusting and $24 \%$ erect (18\% articulated and $6 \%$ rigid). These proportions are similar in Recent communities and in some fossil assemblages in tropical coral reef environments (Winston, 1986; Cheetham and Jackson, 2000; Di Martino et al., 2015). The principal substrates encrusted by bryozoans were the scleractinian corals Alveopora tampae, Acropora panamensis, Colpophyllia willoughbiensis, Goniopora hilli, Porites anguillensis, Porites baracoaensis, Acropora sp., Porites sp., Caryophyllidae gen. et sp. indet., the hydrocoral Millepora sp., as well as coralline algae and mollusk shells.

Species richness varies greatly among the three sampling localities: $75 \%$ of species were found in Arroyo Ekieps, 25\% in Uitpa, and $3 \%$ in Flor de La Guajira (Appendix 2). The highest species richness in Arroyo Ekieps is associated with a higher structural complexity compared to the small patch reefs in Arroyo Uitpa and Flor de La Guajira. A single species, Hippopleurifera sp. indet. 1, was found in Flor de La Guajira, and was also present in Arroyo Uitpa. The remaining species are exclusive to each locality.

Except for the three newly introduced genera, Atoichos, Gymnophorella (Flórez et al., 2021), and Cycloavicularia n. gen., the genera found in the Siamaná Formation have been observed previously in the Great Caribbean Region, Gulf of Mexico, and north of Brazil, either exclusively in the fossil record or contemporary environments, or both. For eight genera, the age range was extended back to the early Miocene (Aquitanian) (Fig. 17). Glabrilaria stands-out among these, because it has only recently been found in the Caribbean region associated with Recent deep-sea coral banks (Rosso et al., 2018) and off the Amazon River mouth in bryozoan reefs (Ramalho et al., 2021).

The Neogene bryozoan fauna associated with shallowwater paleoenvironments from the Gulf of Mexico and the Caribbean Basin is relatively well studied (Cheetham et al., 1999; Di Martino et al., 2018). In other tropical regions from South America, such northern Brazil, studies are incipient and knowledge of early Miocene bryozoans is partial (Zágoršek et al., 2014; Ramalho et al., 2015, 2019; Aguilera et al., 2020). However, compared to these faunas, in which erect and free-living species are dominant (Cheetham and Jackson, 1996; Ramalho et al., 2015, 2019; Di Martino et al., 2018), the Siamaná bryozoan assemblage shows a different ecological pattern and taxonomic composition at the genus level. In addition to the assemblage being older (Aquitanian), with the exception of the Brazilian fauna, these differences may be attributed to the reefal paleoenvironment, which favors cryptic, encrusting species colonizing the coral framework, as also observed in other tropical regions (Di Martino and Taylor, 2014, 2015). Nonetheless, genera such as Margaretta and Nellia are present throughout the regions over time.

Compared to other bryozoan faunas associated with Miocene coral reefs, the species richness in the Siamaná Formation is significantly lower (e.g., 123 species were reported from Indonesia [Di Martino and Taylor, 2014, 2015] and 56 species from the Mediterranean [Hamdane and Moissette, 2002]). These differences may be an effect of sampling effort in fresh exposures. In addition, the greater bryozoan diversity of the Indonesian reefs can be explained by the high input of siliciclastic sediment that facilitates the preservation of the material (Di Martino et al., 


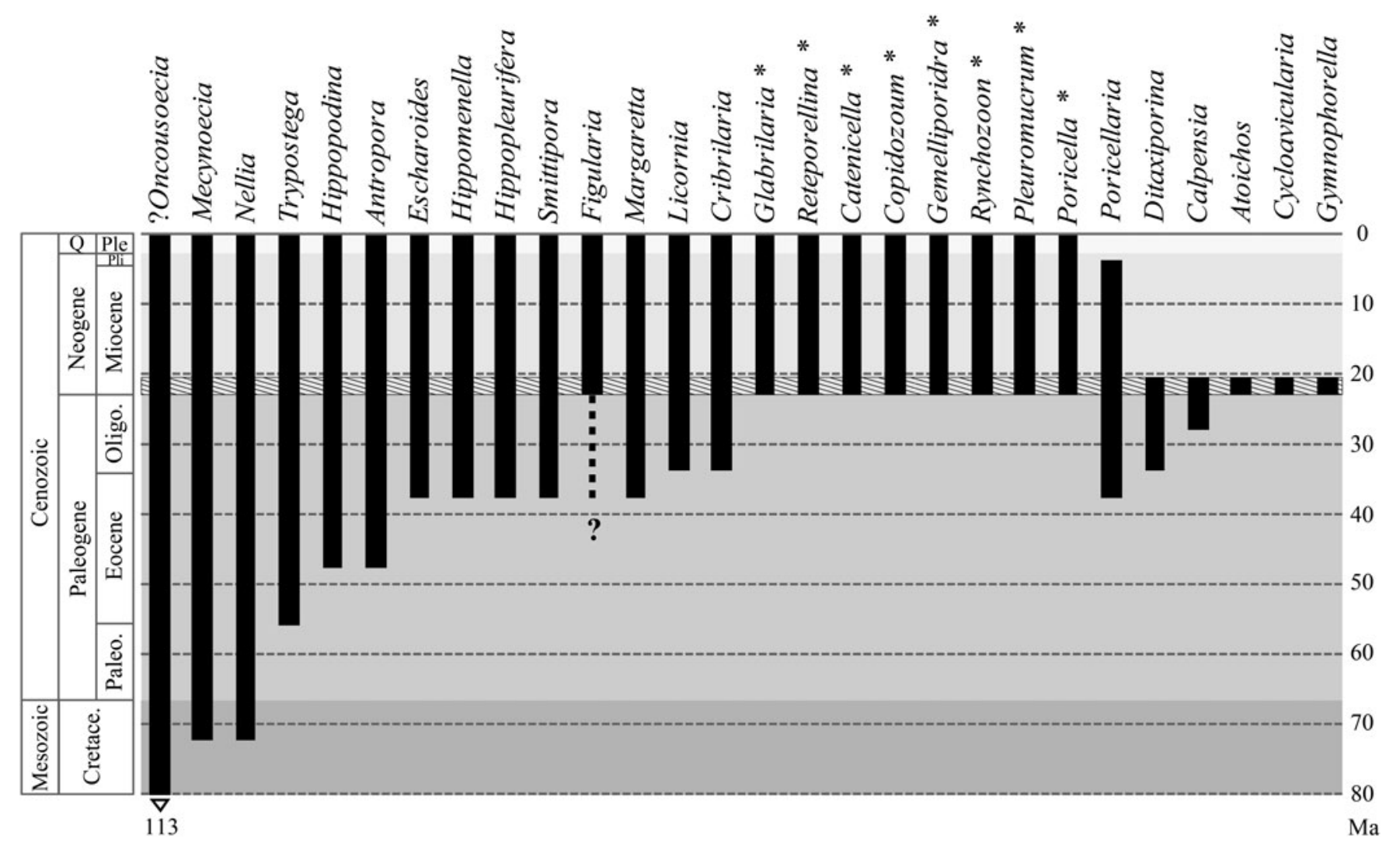

Figure 17. Range chart of the first and last occurrences in the greater Caribbean region, Gulf of Mexico, and Brazil, of the genera reported here and in Flórez et al. (2021); asterisks indicate the genera whose ranges have been extended to the early Miocene. The striped interval is the estimated stratigraphic range for the reefs of the Siamaná Formation (ca. 23-20.5 Ma). References: Canu and Bassler (1917, 1920, 1923); Cheetham (1962a, b, 1963); Winston (1984, 1986, 2005); Winston and Cheetham (1984); Cheetham et al. (1999, 2007); Taylor (2001); Taylor and McKinney (2006); Flórez et al. (2007, 2021); Montoya-Cadavid et al. (2007); Di Martino et al. (2017, 2019); Rosso et al. (2018); Martha et al. (2019); Ramalho et al. (2019, 2021).

2015), including the calcitization of originally aragonitic taxa (Di Martino et al., 2016).

The bryozoan fauna of the Siamaná Formation highlights the remarkable diversity of cryptic species in the ancient coral reefs of the Southern Caribbean region.

\section{Acknowledgments}

We thank P. Zapata for collecting the coral samples (Colciencias Project 727756933195); J.C. Braga and C. Jaramillo for their comments and support; R. Cuffey and P. Bock for helping with the bibliography; J. Souto, C. López-Fé, and L.M. Vieira for taxonomic advice; Corporación Geológica ARES for the logistics and the Wayúu community for the guide in field. We are grateful for the support of Ecopetrol S.A., STRI, University of Zurich, Universidad del Norte, NSF (Grant EAR 0957679), National Geographic Society, Anders Foundation, 1923 Fund, and G.D. and J. Walston Johnson during the expeditions. The research group of the Junta de Andalucía RNM 190 supported SEM work and the Universidad de Granada the open access fees. PF was funded by the Colciencias scholarship Doctorados en el Exterior 728. EDM was funded by the Research Council of Norway grant 314499. We are grateful to the reviewers, J. López-Gappa and B. Berning, and to the Associate Editor, P.D. Taylor, for their valuable comments that greatly improved the first submitted version of this manuscript.

\section{References}

Abbas, H.L., and El-Senoussi, Y.I., 1979, A study of some Miocene Bryozoa from Umm El-Rakham area, west of Mersa Matruh, Western Desert: Proceedings of the Egyptian Academy of Sciences, v. 29, p. 153-174.

Abildgaard, P.C., 1806, Decripsit et tabulas, in Müller, O.F., ed., Zoologica Danica, Seu, Animalium Daniae et Norvegiae Rariorum ac Minus Notorum Descriptiones et Historia: Copenhagen, Hafniae, v. 4, p. 1-46.

Aguilera, O., Bencomo, K., de Araújo, O.M.O., Dias, B.B., Coletti, G., Lima, D., da Silva-Caminha, S.A.F., Polk, M., Alves-Martins, M.V., Jaramillo, C., Kutter, V.T., and Lopes R.T., 2020, Miocene heterozoan carbonate systems from the western Atlantic equatorial margin in South America: the Pirabas Formation: Sedimentary Geology, v. 407, p. 1-28.

Almeida, A.C.S., Souza, F.B.C., Menegola, C.M.S., and Vieira, L.M., 2017, Diversity of marine bryozoans inhabiting demosponges in northeastern Brazil: Zootaxa, v. 4290, p. 281-323.

Audouin, J.V., 1826, Explication sommaire des planches de polypes de l'Egypte et de la Syrie, publiées par Jules-Cesar Savigny, in Audouin, J.V., ed., Description de L'Egypte, ou Recueil des Observations et des Recherches qui Ont Été Faites en Egypte Pendant l'Expédition de l'Armée Française. Histoire Naturelle 1: Paris, Imprimerie Impériale, 339 p.

Bastos, A.C., Moura, R.L., Moraes, F.C., Vieira, L.S., Braga, J.C., Ramalho, L.V., Amado-Filho, G.M., Magdalena, U.R. and Webster, J.M., 2018, Bryozoans are major modern builders of South Atlantic oddly shaped reefs: Scientific Reports, v. 8, p. 1-11.

Berning, B., 2006, The cheilostome bryozoan fauna from the late Miocene of Niebla (Guadalquivir Basin, SW Spain): environmental and biogeographic implications: Mitteilungen aus dem Geologisch-Paläontologischen Institut der Universität Hamburg, v. 90, p. 7-156.

Berning, B., 2012, Taxonomic notes on some Cheilostomata (Bryozoa) from Madeira: Zootaxa, v. 3236, p. 36-54.

Berning, B., 2013, New and little-known Cheilostomata (Bryozoa, Gymnolaemata) from the NE Atlantic: European Journal of Taxonomy, v. 44, p. 1-25. 
Bobies, C.A., 1956, Bryozoenstudien. I. Die Bryozoenfauna der tortonen Strandbildungen von Kalksburg bei Wien: Jahrbuch der Geologischen Bundesanstalt, v. 99, p. 225-258.

Busk, G., 1852, Catalogue of Marine Polyzoa in the Collection of the British Museum. I. Cheilostomata: London, Trustees of the British Museum, 54 p.

Busk, G., 1859, A Monograph of the Fossil Polyzoa of the Crag: London, Palaeontographical Society, $136 \mathrm{p}$.

Busk, G., 1884, Report on the Polyzoa collected by H.M.S. Challenger during the years 1873-1876. Part 1. The Cheilostomata. Report on the Scientific Results of the Voyage of the H.M.S. Challenger during the years 1873 76: Zoology, v. 10, part 30, p. 1-216.

Canu, F., 1904, Étude de bryozoaires tertiaries recueillis en 1885 et 1886 par M.Ph. Thomas dans la région sud de la Tunisie: Exploration Scientifique de la Tunisie: Paléontologie: Paris, Imprimerie nationale, p. 1-37.

Canu, F., and Bassler, R.S., 1917, A synopsis of American early Tertiary cheilostome Bryozoa: United States National Museum Bulletin, v. 96, p. 1-87.

Canu, F., and Bassler, R.S., 1919, Fossil Bryozoa from the West Indies: Publications of the Carnegie Institution, v. 291, p. 75-102.

Canu, F., and Bassler, R.S., 1920, North American early Tertiary Bryozoa: United States National Museum Bulletin, v. 106, p. 1-879.

Canu, F., and Bassler, R.S., 1923, North American later Tertiary and Quaternary Bryozoa: United States National Museum Bulletin, v. 125, p. 1-302.

Canu, F., and Bassler, R.S., 1925, Les Bryozoaires du Maroc et de Mauritanie: Mémoires de la Société des Sciences Naturelles du Maroc, v. 10, p. 1-79.

Canu, F., and Bassler, R.S., 1927, Classification of the cheilostomatous Bryozoa: Proceedings of the U.S. National Museum, v. 69, p. 1-42.

Canu, F., and Bassler, R.S., 1928, Fossil and Recent Bryozoa of the Gulf of Mexico region: Proceedings of the U.S. National Museum, v. 72, p. 1-199.

Cardenas, D., Jaramillo, C., and Oboh-Ikuenobe, F., 2020, Early Miocene marine palynology of the Colombian Caribbean margin: biostratigraphic and paleoceanographic implications: Palaeogeography, Palaeoclimatology, Palaeoecology, v. 558, 109955. https://doi.org/10.1016/j.palaeo.2020. 109955.

Cheetham, A.H., 1962a, The polyzoan genus Ditaxiporina Stach: Annals and Magazine of Natural History, v. 13, p. 485-490.

Cheetham, A.H., 1962b, Eocene Bryozoa from the McBean Formation in Georgia: Micropaleontology, v. 8, p. 323-336.

Cheetham, A.H., 1963, Late Eocene zoogeography of the eastern Gulf Coast region: Memoirs of the Geological Society of America, v. 91, p. 1-113.

Cheetham, A.H., and Jackson, J.B.C., 1996, Speciation, extinction, and the decline of arborescent growth in Neogene and Quaternary cheilostome Bryozoa of tropical America, in Jackson, J.B.C., Budd, A.F., and Coates, A.G., eds., Evolution and Environment in Tropical America: Chicago, University of Chicago Press, p. 205-233.

Cheetham, A.H., and Jackson, J.B.C., 2000, Neogene history of cheilostome Bryozoa in tropical America, in Herrera-Cubilla, A., and Jackson, J.B.C., eds., Proceedings of the 11th International Bryozoology Association Conference: Balboa, Panama, Smithsonian Tropical Research Institute, p. 1-16.

Cheetham, A.H., and Sandberg, P.A., 1964, Quaternary Bryozoa from Louisiana mudlumps: Journal of Paleontology, v. 38, p. 1013-1046.

Cheetham, A.H., Jackson, J.B.C., Sanner, J., and Ventocilla, Y., 1999, Neogene cheilostome Bryozoa of tropical America: comparison and contrast between the Central American Isthmus (Panama, Costa Rica) and the north-central Caribbean (Dominican Republic): Bulletin of American Paleontology, v. 357, p. 159-192.

Cheetham, A.H., Sanner, J., and Jackson, J.B.C., 2007, Metrarabdotos and related genera (Bryozoa: Cheilostomata) in the late Paleogene and Neogene of tropical America: Journal of Paleontology, v. 81, p. 1-91.

Cook, P.L., 1968, Polyzoa from West Africa. The Malacostega. Part. I: Bulletin of the British Museum (Natural History), Zoology, v. 16, p. 115-160.

Cook, P.L., 1977, The genus Tremogasterina Canu (Bryozoa, Cheilostomata): Bulletin of the British Museum (Natural History), Zoology, v. 35, p. 103-165.

Cuffey, R.J., 2011, Bryozoa, in Hopley, D., ed., Encyclopedia of Modern Coral Reefs. Part 2. Structure, Form and Process: Dordrecht, Springer, p. 172-177.

David, L., 1965, Bryozoaires du Néogène du Bassin du Rhône: gisements vindoboniens de la région Lyonnaise: Travaux des Laboratoires de Géologie de la Faculté des Sciences de Lyon, v. 12, p. 33-86.

de Blainville, H.M.D., 1830, Zoophytes, in Levrault, F.G., ed., Dictionnaire des Sciences Naturelles, dans lequel on Traité Méthodiquement des Differéns Êtres de la Nature, Considérés soit en Eux-mêmes, d'Après l'État Actuel de nos Connoissances, Soit Relativement a l'Utilité qu'en Peuvent Retirer la Médicine, l'Agriculture, le Commerce et les Arts: Paris, Le Normat, v. 60 , p. $1-548$.

Delgadillo-G. [Delgadillo-Garzón], O., and Flórez, P., 2015, Primeros registros del Phylum Bryozoa asociados a hábitats artificiales en el Caribe colombiano: Latin American Journal of Aquatic Research, v. 43, p. 33-45.

d'Hondt, J.L., 1981, Bryozoaires cheilostomes bathyaux et abyssaux provenant des campagnes océanographiques américaines (1969-1972) de 1'“Atlantis II" du "Chain" et du "Knorr" (Woods Hole Oceanographic Institution):
Bulletin du Muséum national d'Histoire naturelle, section A (sér. 4), v. 3, p. 5-71.

Di Martino, E., and Taylor, P.D., 2014, Miocene Bryozoa from East Kalimantan, Indonesia. Part 1: Cyclostomata and 'Anascan' Cheilostomata: Scripta Geologica, v. 146, p. 17-126.

Di Martino, E., and Taylor, P.D., 2015, Miocene Bryozoa from East Kalimantan, Indonesia. Part II: 'Ascophoran' Cheilostomata: Scripta Geologica, v. 148, p. 1-142.

Di Martino, E., and Taylor, P.D., 2017, Some Miocene cheilostome bryozoan genera of Michel Vigneaux - systematic revision and scanning electron microscopic study: Geodiversitas, v. 39, p. 783-796.

Di Martino, E., Taylor, P.D., and Johnson, K.G., 2015, Bryozoan diversity in the Miocene of the Kutai Basin, East Kalimantan, Indonesia: Palaios, v. 30 , p. 109-115.

Di Martino, E., Taylor, P.D., Kudryavtsev, A.B., and Schopf, J.W., 2016, Calcitization of aragonitic bryozoans in Cenozoic tropical carbonates from East Kalimantan, Indonesia: Facies, v. 62, no. 11, p. 1-15.

Di Martino, E., Taylor, P.D., and Portell, R.W., 2017, Bryozoans from the lower Miocene Chipola Formation, Calhoun County, Florida, USA: Bulletin of the Florida Museum of Natural History, v. 53, p. 97-200.

Di Martino, E., Jackson, J.B.C., Taylor, P.D., and Johnson, K.G., 2018, Differences in extinction rates drove modern biogeographic patterns of tropical marine biodiversity: Science Advances, v. 4, eaaq1508. https://doi.org/10. 1126/sciadv.aaq1508.

Di Martino, E., Taylor, P.D., and Portell, R.W., 2019, Anomia-associated bryozoans from the upper Pliocene (Piacenzian) lower Tamiami Formation of Florida, USA: Palaeontologia Electronica, 22.1.11. https://doi.org/10. $26879 / 920$.

Duque-Caro, H., 1974, Los foraminíferos planctónicos y el Terciario de Colombia: Revista Española de Micropaleontología, v. 7, p. 403-427.

Ellis, J., and Solander, D.C., 1786, The Natural History of Many Curious and Uncommon Zoophytes, Collected from Various Parts of the Globe: London, White and Elmsly, $206 \mathrm{p}$.

Flórez, P., 2020, Corals and bryozoans from the early Miocene coral reefs in La Guajira (northern Colombia) [Ph.D. dissertation]: Granada, Universidad de Granada, $180 \mathrm{p}$.

Flórez, P., Montoya-Cadavid, E., Reyes-Forero, J., and Santodomingo, N., 2007, Briozoos cheilostomados del Caribe colombiano: Boletín de Investigaciones Marinas y Costeras, Invemar, v. 36, p. 229-250.

Flórez, P., Zapata-Ramírez, P., and Klaus, J.S., 2019a, Early Miocene shallowwater corals from La Guajira, Colombia. Part I, Acroporidae-Montastraeidae: Journal of Paleontology, v. 93, p. 1-24.

Flórez, P., Zapata-Ramírez, P., and Klaus, J.S., 2019b, Early Miocene shallowwater corals from La Guajira, Colombia. Part II, Mussidae-Siderastreidae and Milleporidae: Journal of Paleontology, v. 93, p. 416-436.

Flórez, P., Di Martino, E., and Ramalho, L.V., 2021, Early Miocene coral reefassociated bryozoans from Colombia. Part I: Cyclostomata, "Anasca" and Cribrilinoidea Cheilostomata: Journal of Paleontology, v. 95, p. 694-719.

Gabb, W.M., and Horn, G.H., 1862, The fossil Polyzoa of the Secondary and Tertiary formations of North America: Journal of the Academy of Natural Sciences of Philadelphia, v. 5, p. 111-179.

Gordon, D.P., 1984, The marine fauna of New Zealand: Bryozoa: Gymnolaemata from the Kermadec Ridge: New Zealand Oceanographic Institute Memoir, v. 91, p. 1-198.

Gordon, D.P., 1989, Intertidal bryozoans from coral reef-flat rubble in Sa'aga, Western Samoa: New Zealand Journal of Zoology, v. 16, p. 447-463.

Gordon, D.P., 2014, Interim classification for Treatise. Version 6 of August 2014. Unpublished. https://www.bryozoa.net/famsys.html.

Gordon, D.P., and Braga, G., 1994, Bryozoa: living and fossil species of the catenicellid subfamilies Ditaxiporinae Stach and Vasignyellinae nov., in Crosnier, A., ed., Résultats des Campagnes MUSORSTOM, 12: Mémoires du Muséum national d'Histoire naturelle, v. 161, p. 55-85.

Graham, N.A.J., and Nash, K.L., 2013, The importance of structural complexity in coral reef ecosystems: Coral Reefs, v. 32, p. 315-326.

Gray, J.E., 1843, Additional radiated animals and Annelides, in Dieffenbach, E., ed., Travels in New Zealand: With Contributions to the Geography, Geology, Botany, and Natural History of that Country: London, John Murray, v. 2, p. 292-295.

Hamdane, A., and Moissette, P., 2002, Bryozoan distribution in a Messinian coral reef complex of western Algeria, in Wyse-Jackson, P.N., Buttler, C.J., and Spencer-Jones, M., eds., Bryozoan Studies 2001: Tokyo: Lisse, Abingdon, Exton, A.A. Balkema Publishers, p. 141-149.

Harmer, S.F., 1933, The genera of Reteporidae: Proceedings of the Zoological Society of London, v. 1933, p. 615-627.

Harmer, S.F., 1957, The Polyzoa of the Siboga Expedition. Part 4. Cheilostomata Ascophora II: Siboga Expedition Reports, v. 28d, p. 641-1147.

Hayward, P.J., and Thorpe, J.P., 1988, Species of Arachnopusia (Bryozoa: Cheilostomata) collected by Discovery investigations: Journal of Natural History, v. 22, p. 773-799. 
Hincks, T., 1895, Contributions towards a general history of the marine Polyzoa, 1880-1891. Appendix 5: London, T. Hincks, p. 1-6.

Jaramillo, C., Sepulchre, P., Cardenas, D., Correa-Metrio, A., Moreno, J.E., Trejos, R., Vallejo, D., Hoyos, N., Martínez, C., Carvalho, D., Escobar, J., Oboh-Ikuenobe, F., Prámparo, M.B., and Pinzón, D., 2020, Drastic vegetation change in the Guajira Peninsula (Colombia) during the Neogene: Paleoceanography and Paleoclimatology, v. 35, e2020PA003933. https://doi.org/ 10.1029/2020PA003933.

Johnston, G., 1838, A History of British Zoophytes: London and Dublin, W.H. Lizars, $341 \mathrm{p}$

Johnston, G., 1847, A History of British Zoophytes Vol. 1: London, van Voorst, $499 \mathrm{p}$.

Jullien, J., 1883, Dragages du 'Travailleur'. Bryozoaires, espèces draguées dans l'Océan Atlantique en 1881: Bulletin de la Société Zoologique de France, v. 7 , p. $497-529$.

Jullien, J., 1888, Bryozoaires. Mission scientifique du Cap Horn 1882-1883. Zoologie: Paris, Gauthier-Villars et fils, v. 6, p. 1-92.

Lagaaij, R., 1963, New additions to the bryozoan fauna of the Gulf of Mexico: Institute of Marine Science Publication, v. 9, p. 181-236.

Lamarck, J.B.P.A., 1816, Les Polypes. Histoire Naturelle des Animaux sans Vertèbres: Paris. Verdiere, v. 2, 568 p.

Leca, L., and d'Hondt, J.L., 1993, Hippopetraliella tahitiensis n. sp., nouveau Bryozoaire Cheilostome (Petraliellidae) de Polynésie Française: Cahiers de Biologie Marine, v. 34, p. 401-409.

Levinsen, G.M.R., 1909, Morphological and Systematic Studies on the Cheilostomatous Bryozoa: Copenhagen, Nationale Forfatterers Forlag, 431 p.

Linnaeus, C., 1758, Systema Naturae per Regna Tria Naturae, Secundum Classes, Ordines, Genera, Species, cum Characteribus, Differentiis, Synonymis, Locis. Editio Decima, Reformata, v. 2: Holmiae, Laurentii Salvii, $824 \mathrm{p}$.

Macintyre, I.G., 2011, Submarine lithification, in Hopley, D., ed., Encyclopedia of Modern Coral Reefs. Part 2. Structure, Form and Process: Dordrecht, Springer, p. 1052-1058.

Marcus, E., 1955, Notas sôbre briozoos marinhos brasileiros: Arquivos do Museu Nacional do Rio de Janeiro, v. 42, p. 273-342.

Martha, S.O., Taylor, P.D., and Rader, W.L., 2019, Early Cretaceous cyclostome bryozoans from the early to middle Albian of the Glen Rose and Walnut formations of Texas, USA: Journal of Paleontology, v. 93, p. 244-259.

McGuirt, J.W., 1941, Louisiana Tertiary Bryozoa: Geological Bulletin, Louisiana State Department of Conservation, v. 21, p. 1-74.

Milne-Edwards, H., 1836, Observations sur les polypiers fossiles du genre Eschara: Annales des Sciences Naturelles, Zoologie (sér. 2), v. 6, p. 321-345.

Montoya-Cadavid, E., Flórez, P., and Winston, J.E., 2007, Checklist of the marine Bryozoa of the Colombian Caribbean: Revista Biota Colombiana, v. 8, p. $159-189$

Neviani, A, 1895a, Briozoi fossili della Farnesina e Monte Mario presso Roma: Palaeontographia Italica, v. 1, p. 77-140.

Neviani, A., 1895b, Nota preliminare sui Briozoi fossili del postpliocene antico della Farnesina e Monte Mario: Bolletino della Società Romana per gli studi Zoologici, v. 4, p. 65-74.

NMiTA Database, 1996-2016, Neogene Marine Biota of Tropical America. https:// fossils.its.uiowa.edu/database/bryozoa/brymnsc.htm. [accessed November 2019]

Norman, A.M., 1864, On undescribed British Hydrozoa, Actinozoa and Polyzoa: Annals and Magazine of Natural History, v. 13, p. 82-90.

Osburn, R.C., 1914, The Bryozoa of the Tortugas Islands, Florida: Carnegie Institution of Washington Publication, v. 182, p. 183-222.

Osburn, R.C., 1940, Bryozoa of Porto Rico with a resume of West Indian bryozoan fauna: Scientific Survey of Porto Rico and the Virgin Islands, v. 16, p. $321-486$.

Osburn, R.C., 1952, Bryozoa of the Pacific coast of America, part 2, Cheilostomata-Ascophora: Report of the Allan Hancock Pacific Expeditions, v. 14, p. 271-611.

Pearman, J.K., Leray, M., Villalobos, R., Machida, R.J., Berumen, M.L., Knowlton, N., and Carvalho, S., 2018, Cross-shelf investigation of coral reef cryptic benthic organisms reveals diversity patterns of the hidden majority: Scientific Reports, v. 8, 8090. https://doi.org/10.1038/s41598-018-26332-5

Poluzzi, A., 1977, Contributi per una revisione del genere Teuchopora Neviani 1895 (Bryozoa, Cheilostomata): Bollettino della Società Paleontologica Italiana, v. 16, p. 69-77.

Powell, N.A., and Cook, P.L., 1967, Notes on Tremogasterina Canu and Tremogasterina robusta (Hincks) (Polyzoa, Ascophora): Cahiers de Biologie Marine, v. 8, p. 2-20.

Ramalho, L.V., Taylor, P.D., and Muricy, G., 2014, New records of Catenicella de Blainville, 1830 (Catenicellidae: Cheilostomata: Ascophora) in Rio de Janeiro State, Brazil: Check List, v. 10, p. 170-174.

Ramalho, L.V., Távora, V.A., Tilbrook, K.J., and Zágoršek, K., 2015, New species of Hippopleurifera (Bryozoa, Cheilostomata) from the Miocene Pirabas Formation, Pará State, Brazil: Zootaxa, v. 3999, p. 125-134.
Ramalho, L.V., Taylor, P.D., Moraes, F.C., Moura, R., Amado-Filho, G.M., and Bastos, A.C., 2018, Bryozoan framework composition in the oddly shaped reefs from Abrolhos Bank, Brazil, southwestern Atlantic: taxonomy and ecology: Zootaxa, v. 4483, p. 155-186.

Ramalho, L.V., Serrano, F., Rueda, J.L., Távora, V.A., and Zágoršek, K., 2019, New update on the bryozoan assemblage of the Miocene Pirabas Formation, Brazil, in Schmidt, R., Reid, C.M., Gordon, D.P., Walker-Smith, G. and Percival, I.P., eds., Bryozoan Studies. Proceedings of the 17th International Bryozoology Conference, Melbourne, Australia, 2016: Sydney, Australasian Palaeontologists, p. 109-114.

Ramalho, L.V., Moraes, F.C., Salgado, L.T., Bastos, A.C., and Moura, R.L., 2021, Bryozoa from the reefs off the Amazon River mouth: checklist, thirteen new species, and notes on their ecology and distribution: Zootaxa, v. 4950 , p. $1-45$.

Renz, O., 1960, Geología de la parte sureste de la Península de La Guajira: Memorias del Tercer Congreso Geológico Venezolano: Boletín Geológico, Publicación Especial, v. 1, p. 317-347.

Reuss, A.E., 1847, Die fossilen Polyparien des Wiener Tertiärbeckens: Haidingers Naturwissenschaftlichen Abhandlungen, v. 2, p. 1-109.

Reuss, A.E., 1874, Die fossilen Bryozoen der Österreichisch-ungarischen Miocäns: Sitzungberichte der kaiserlichen Akademie der Wissenschaften, Wien, v. 33, p. 219-222.

Rollins, J., 1965, Stratigraphy and structure of the Guajira Peninsula, northwestern Venezuela and northeastern Colombia: University of Nebraska Studies, v. 30, p. 1-1102.

Rosso, A., Beuck, L., Vertino, A., Sanfilippo, R., and Freiwald, A., 2018, Cribrilinids (Bryozoa, Cheilostomata) associated with deep-water coral habitats at the Great Bahama Bank slope (NW Atlantic), with description of new taxa: Zootaxa, v. 4524, p. 401-439.

Silva-Tamayo, J.C., Lara, M.E., Nana Yobo, L., Erdal, Y.D., Sanchez, J., and Zapata-Ramírez, P.A., 2017, Tectonic and environmental factors controlling on the evolution of Oligo-Miocene shallow marine carbonate factories along a tropical SE Circum-Caribbean: Journal of South American Earth Sciences, v. 78, p. 213-237.

Smitt, F.A., 1873, Floridan Bryozoa collected by Count L.F. de Pourtales, Part 2: Kongliga Svenska Vetenskaps-Akademiens Handlingar, v. 11, p. $1-83$.

Stach, L.W., 1935, The genera of Catenicellidae: Proceedings of the Royal Society of Victoria, v. 47, p. 389-396.

Taylor, P.D., 2001, Preliminary systematics and diversity patterns of cyclostome bryozoans from the Neogene of the Central American Isthmus: Journal of Paleontology, v. 75, p. 578-589.

Taylor, P.D., and Di Martino, E., 2014, Why is the tropical Cenozoic fossil record so poor for bryozoans?, in Rosso, A., Wyse-Jackson, P.N., and Porter, J., eds., Bryozoans Studies 2013: Studi Trentini di Scienze Naturali, v. 94, p. $249-257$.

Taylor, P.D., and Foster, T.S., 1994, Bryozoa from the Plio-Pleistocene of Tobago, West Indies: Tertiary Research, v. 15, p. 1-16.

Taylor, P.D., and McKinney, F.K., 2006, Cretaceous Bryozoa from the Campanian and Maastrichtian of the Atlantic and Gulf Coastal plains, United States: Scripta Geologica, v. 132, p. 1-346.

Teatin, P., 1991, The Siamaná Formation Carbonate Unit, Lower Guajira SubBasin, Colombia: Its Depositional Setting and Diagnosis [M.Sc. thesis] Columbia, University of South Carolina, $131 \mathrm{p}$.

Tilbrook, K.J., 1999, Description of Hippopodina feegeensis and three other species of Hippopodina Levinsen, 1909 (Bryozoa: Cheilostomatida): Journal of Zoology, v. 247, p. 449-456.

Tilbrook, K.J., 2006, Cheilostomatous Bryozoa from the Solomon Islands: Santa Barbara Museum of Natural History Monographs, no. 4, Studies in Biodiversity, no. $3,386 \mathrm{p}$.

Vaughan, T.W., 1919, Fossil corals from Central America, Cuba and Porto Rico, with an account of the American Tertiary, Pleistocene, and Recent coral reef: United States National Museum Bulletin, v. 103, p. 189-524.

Vieira, L.M., Gordon, D.P., and Correia, M.D., 2007, First record of a living ditaxiporine catenicellid in the Atlantic, with a description of Vasignyella ovicellata n. sp. (Bryozoa): Zootaxa, v. 152, p. 49-58.

Vieira, L.M., Migotto, A.E., and Winston, J.E., 2010, Marcusadorea, a new genus of lepralioid bryozoan from warm waters: Zootaxa, v. 2348, p. 57-68.

Vigneaux, M., 1949, Révision des Bryozoaires néogènes du Bassin d'Aquitaine et essai de classification: Mémoires de la Société Géologique de France, v. 28 , p. $1-153$.

Waters, A.W., 1891, North-Italian Bryozoa: Quarterly Journal of the Geological Society of London, v. 47, p. 1-34.

Waters, A.W., 1899, Bryozoa from Madeira: Journal of the Royal Microscopical Society, v. 1899, p. 6-16.

Weisbord, N.E., 1973, New and little-known corals from the Tampa Formation of Florida: Geological Bulletin, State of Florida Department of Natural Resources, Division of Interior Resources, Bureau of Geology, v. 56, p. 1-157. 
Winston, J.E., 1982, Marine bryozoans (Ectoprocta) of the Indian River area, Florida: Bulletin of the American Museum of Natural History, v. 173, p. 99-176.

Winston, J.E., 1984, Shallow-water bryozoans of Carrie Bow Bay, Belize: American Museum Novitates, v. 2799, p. 1-38.

Winston, J.E., 1986, An annotated checklist of coral-associated bryozoans: American Museum Novitates, v. 2859, p. 1-39.

Winston, J.E., 2005, Re-description and revision of Smitt's "Floridan Bryozoa" in the collection of the Museum of Comparative Zoology, Harvard University: Virginia Museum of Natural History Memoir 7, $147 \mathrm{p}$.

Winston, J.E., and Cheetham, A.H., 1984, The Bryozoan Nellia tenella as a living fossil, in Eldredge, N., and Stanley, S., eds., Living Fossils: New York, Springer Verlag, p. 257-265.

Winston, J.E., and Jackson, J.B.C., 1984, Ecology of cryptic coral-reef communities. IV. Community development and life histories of encrusting cheilostome Bryozoa: Journal of Experimental Marine Biology and Ecology, v. 76, p. 1-21.
Winston, J.E., and Vieira, L.M., 2013, Systematics of interstitial encrusting bryozoans from southeastern Brazil: Zootaxa, v. 3710, p. 101-146.

Winston, J.E., and Woollacott, R.M., 2009, Scientific results of the Hassler Expedition. Bryozoa. No.1. Barbados: Bulletin of the Museum of Comparative Zoology, v. 159, p. 239-300.

Winston, J.E., Vieira, L.M., and Woollacott, R.M., 2014, Scientific results of the Hassler Expedition. Bryozoa. No. 2. Brazil: Bulletin of the Museum of Comparative Zoology, v. 161, p. 139-239.

Zágoršek, K., Ramalho, L.V., Berning, B., and Távora, V.A., 2014, A new genus of the family Jaculinidae (Cheilostomata, Bryozoa) from the Miocene of the tropical western Atlantic: Zootaxa, v. 3838, p. 98-112.

Accepted: 8 September 2021 


\section{Appendices}

Appendix 1. Localities, stations and coordinates of the Siamaná Formation in the studied area. Geologic ages inferred from strontium isotopes in coralline algae (Silva-Tamayo et al., 2017), and faunistic assemblages found in the studied outcrops (Flórez et al., 2021).

\begin{tabular}{|c|c|c|c|c|}
\hline Locality & Station code & Latitude N & Longitude W & Geologic age \\
\hline Arroyo Ekieps & 550008 & $12^{\circ} 04^{\prime} 11.02^{\prime \prime}$ & $71^{\circ} 26^{\prime} 23.09^{\prime \prime}$ & Early Miocene \\
\hline Arroyo Ekieps & 550011 & $12^{\circ} 04^{\prime} 08.06^{\prime \prime}$ & $71^{\circ} 26^{\prime} 22.2^{\prime \prime}$ & Early Miocene \\
\hline Arroyo Ekieps & 550012 & $12^{\circ} 03^{\prime} 5.70^{\prime \prime}$ & $71^{\circ} 25^{\prime} 10.80^{\prime \prime}$ & Early Miocene \\
\hline Arroyo Uitpa & 550006 & $12^{\circ} 01^{\prime} 49.0^{\prime \prime}$ & $71^{\circ} 25^{\prime} 16.07^{\prime \prime}$ & Early Miocene \\
\hline Flor de La Guajira & 550002 & $11^{\circ} 49^{\prime} 52.08^{\prime \prime}$ & $71^{\circ} 23^{\prime} 58.07^{\prime \prime}$ & Early Miocene? \\
\hline
\end{tabular}


Appendix 2. List of bryozoans found in the Siamaná Formation (Cocinetas Basin in La Guajira Peninsula, Colombia). The collection is hosted at the Mapuka Museum of the Universidad del Norte, Barranquilla-Colombia. Bryozoan colony attached to the coral (*).

\begin{tabular}{|c|c|c|c|c|c|c|c|c|}
\hline Family & Species & $\begin{array}{l}\text { Catalog number } \\
\text { MUN-STRI }\end{array}$ & Locality & $\begin{array}{l}\text { Station } \\
\text { number }\end{array}$ & Type of colony & Substrate & Number of specimens & Coating \\
\hline Arachnopusiidae & Poricella paulae $\mathrm{n} . \mathrm{sp}$. & 47676 & Arroyo Ekieps & 550013 & Encrusting & Millepora sp. & 1 & Coated \\
\hline Arachnopusiidae & Poricella paulae $\mathrm{n} . \mathrm{sp}$. & 47677 & Arroyo Ekieps & 550013 & Encrusting & Acropora sp. & 1 & Uncoated \\
\hline Arachnopusiidae & Poricella paulae n. sp. & 47678 & Arroyo Ekieps & 550013 & Encrusting & Alveopora tampae & 1 & Uncoated \\
\hline Arachnopusiidae & Poricella paulae $\mathrm{n} . \mathrm{sp}$. & 47679 & Arroyo Ekieps & 550013 & Encrusting & Caryophylliidae - Alveopora sp. & 1 & Uncoated* \\
\hline Arachnopusiidae & Poricella paulae n. sp. & 47680 & Arroyo Ekieps & 550013 & Encrusting & Acropora panamensis & 1 & Coated \\
\hline Arachnopusiidae & Poricella paulae n. sp. & 47681 & Arroyo Ekieps & 550013 & Encrusting & Acropora panamensis & 1 & Uncoated \\
\hline Arachnopusiidae & gen. and sp. indet. & 47682 & Arroyo Ekieps & 550013 & Encrusting & Porites baracoaensis & 1 & Coated \\
\hline Catenicellidae & Catenicella sp. indet. & 47666 & Arroyo Ekieps & 550012 & Erect articulated & Acropora panamensis & 18 & Coated/Uncoatec \\
\hline Catenicellidae & Ditaxiporina colombiana $\mathrm{n}$. sp. & 47668 & Arroyo Ekieps & 550012 & Erect articulated & 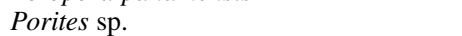 & 1 & Uncoated \\
\hline Catenicellidae & Ditaxiporina colombiana $\mathrm{n}$. sp. & 47667 & Arroyo Ekieps & 550012 & Erect articulated & Goniopora hilli & 8 & Coated \\
\hline Catenicellidae & Ditaxiporina colombiana $\mathrm{n}$. sp. & 47669 & Arroyo Ekieps & 550012 & Erect articulated & Alveopora tampae & 3 & Uncoated \\
\hline Catenicellidae & Ditaxiporina colombiana $\mathrm{n}$. sp. & 47670 & Arroyo Ekieps & 550012 & Erect articulated & Acropora panamensis & 2 & Coated/Uncoated \\
\hline Catenicellidae & Ditaxiporina colombiana $\mathrm{n}$. sp. & 47671 & Arroyo Ekieps & 550012 & Erect articulated & Acropora panamensis & 8 & Uncoated \\
\hline Catenicellidae & Ditaxiporina colombiana $\mathrm{n}$. sp. & 47672 & Arroyo Ekieps & 550012 & Erect articulated & Acropora panamensis & 3 & Coated \\
\hline Hippopodinidae & Hippopodina sp. indet. & 47708 & Arroyo Ekieps & 550013 & Encrusting & Millepora sp. & 1 & Coated \\
\hline Hippopodinidae & Hippopodina sp. indet. & 47707 & Arroyo Ekieps & 550012 & Encrusting & Porites anguillensis & 1 & Coated \\
\hline Teuchoporidae & Cycloavicularia parva n. gen. n. sp. & 47709 & Arroyo Ekieps & 550011 & Encrusting & Porites anguillensis & 1 & Coated \\
\hline Margarettidae & Margaretta cf. M. buski & 47703 & Arroyo Ekieps & 550012 & Erect articulated & Goniopora hilli & 1 & Coated \\
\hline Margarettidae & Margaretta cf. M. buski & 47704 & Arroyo Ekieps & 550012 & Erect articulated & Goniopora hilli & 1 & Uncoated \\
\hline Margarettidae & Margaretta cf. M. buski & 47705 & Arroyo Ekieps & 550013 & Erect articulated & Acropora panamensis & 1 & Coated \\
\hline Margarettidae & Margaretta cf. M. buski & 47706 & Arroyo Ekieps & 550013 & Erect articulated & Acropora panamensis & 1 & Uncoated \\
\hline Phidoloporidae & Rhynchozoon sp. indet. & 47713 & Arroyo Ekieps & 550008 & Encrusting & Millepora alcicornis & 1 & Coated \\
\hline Phidoloporidae & Rhynchozoon sp. indet. & 47714 & Arroyo Ekieps & 550012 & Encrusting & Colpophyllia willoughbiensis & 1 & Uncoated \\
\hline Phidoloporidae & Rhynchozoon sp. indet. & 47715 & Arroyo Ekieps & 550012 & Encrusting & Colpophyllia willoughbiensis & 1 & Uncoated \\
\hline Phidoloporidae & Rhynchozoon sp. indet. & 47716 & Arroyo Ekieps & 550012 & Encrusting & Goniopora hilli & 1 & Coated \\
\hline Phidoloporidae & Rhynchozoon sp. indet. & 47717 & Arroyo Ekieps & 550012 & ?Laminar & Goniopora hilli & 1 & Coated \\
\hline Phidoloporidae & Rhynchozoon sp. indet. & 47718 & Arroyo Ekieps & 550012 & Encrusting & Colpophyllia willoughbiensis & 1 & Coated \\
\hline Phidoloporidae & Reteporellina sp. indet. & 47711 & Arroyo Ekieps & 550013 & Erect rigid & Caryophylliidae - Acropora panamensis & 1 & Coated/Uncoatec \\
\hline Phidoloporidae & Reteporellina $\mathrm{sp}$ indet. & 47712 & Arroyo Ekieps & 550013 & Erect rigid & Acropora panamensis & 1 & Coated/Uncoatec \\
\hline Phidoloporidae & Pleuromисrum sp. indet. & 47710 & Arroyo Uitpa & 550006 & Encrusting & Coralline algae & 1 & Coated \\
\hline Romancheinidae & Hippomenella sp. indet. & 47696 & Arroyo Ekieps & 550013 & Encrusting & Acropora sp. & 1 & Coated \\
\hline Romancheinidae & Hippomenella sp. indet. & 47697 & Arroyo Ekieps & 550013 & Encrusting & Acropora sp. & 1 & Coated \\
\hline Romancheinidae & Hippomenella sp. indet. & 47698 & Arroyo Ekieps & 550013 & Encrusting & Acropora sp. & 1 & Coated/Uncoatec \\
\hline Romancheinidae & Hippomenella sp. indet. & 47699 & Arroyo Ekieps & 550013 & Encrusting & Caryophylliidae - Acropora sp. & 1 & Uncoated \\
\hline Romancheinidae & Hippopleurifera aff. H. mисronata & 47693 & Arroyo Uitpa & 550005 & Encrusting & Porites sp. - Algae & 1 & Coated \\
\hline Romancheinidae & Hippopleurifera aff. H. mucronata & 47694 & Arroyo Uitpa & 550005 & Encrusting & Porites sp. & 1 & Uncoated \\
\hline Romancheinidae & Hippopleurifera aff. H. mucronata & 47695 & Arroyo Uitpa & 550005 & Encrusting & Porites $\mathrm{sp}$. & 1 & Uncoated \\
\hline Romancheinidae & Hippopleurifera sp. indet. 1 & 47686 & Flor de La Guajira & 550002 & Encrusting & Caryophylliidae & 1 & Coated \\
\hline Romancheinidae & Hippopleurifera sp. indet. 1 & 47687 & Arroyo Uitpa & 550005 & Encrusting & Porites sp. - Algae & 1 & Uncoated \\
\hline Romancheinidae & Hippopleurifera sp. indet. 1 & 47688 & Arroyo Uitpa & 550005 & Encrusting & Porites sp. - Algae & 1 & Uncoated \\
\hline Romancheinidae & Hippopleurifera sp. indet. 1 & 47689 & Arroyo Uitpa & 550006 & Encrusting & ?Millepora sp. & 1 & Coated \\
\hline Romancheinidae & Hippopleurifera sp. indet. 1 & 47690 & Arroyo Uitpa & 550006 & Encrusting & ?Millepora sp. & 1 & Coated \\
\hline Romancheinidae & Hippopleurifera sp. indet. 2 & 47691 & Arroyo Ekieps & 550013 & Encrusting & Acropora sp. & 1 & Coated \\
\hline Romancheinidae & Hippopleurifera sp. indet. 2 & 47692 & Arroyo Ekieps & 550013 & Encrusting & Acropora panamensis & 1 & Uncoated \\
\hline Romancheinidae & Escharoides aff. E. martae & 47683 & Arroyo Uitpa & 550006 & Encrusting & Porites sp. & 1 & Coated \\
\hline Romancheinidae & Escharoides aff. E. martae & 47685 & Arroyo Uitpa & 550006 & Encrusting & Porites sp. & 1 & Uncoated \\
\hline Schizoporellidae & Gemelliporidra aff. G. magniporosa & 47700 & Arroyo Ekieps & 550012 & Encrusting & Porites baracoaensis & 1 & Uncoated \\
\hline Schizoporellidae & Gemelliporidra aff. G. magniporosa & 47701 & Arroyo Ekieps & 550012 & Encrusting & Alveopora tampae & 1 & Coated \\
\hline Schizoporellidae & Gemelliporidra aff. G. magniporosa & 47702 & Arroyo Ekieps & 550013 & Encrusting & Acropora sp. & 1 & Coated/Uncoatec \\
\hline Trypostegidae & Trypostega $\mathrm{sp}$. indet. & 47675 & Arroyo Uitpa & 550005 & Encrusting & Porites sp. & 1 & Uncoated \\
\hline
\end{tabular}

